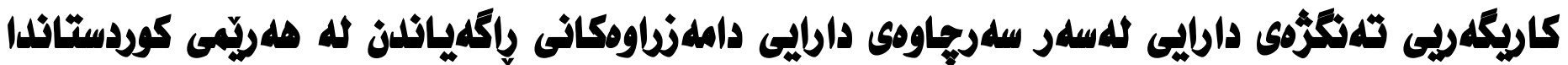

\section{جوانه سلاح حسيز}

jwansalah80@gmail.com : ئيمهيلّ

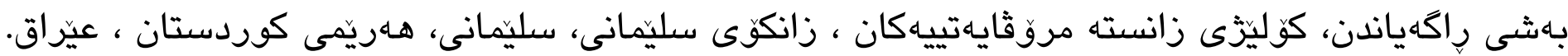
عمر احمد روملزjاز

Oيمهيل: Omar.ramadahn@ouh.edu.iq

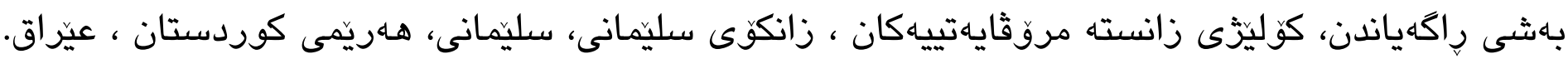

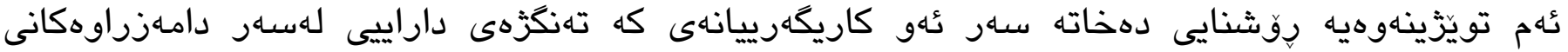

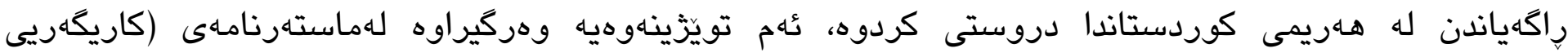

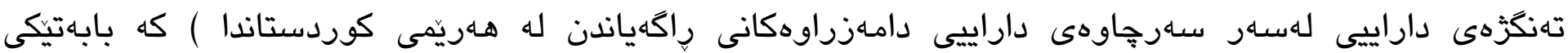

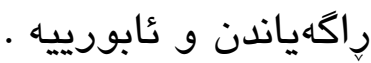
تامانج له تويّزينهوهكه (دهرخستنى كاستى كاريكهريى تهنكزهى دارايييه لهسهر شيّوازى كاركرن له دامهزراوهكانى

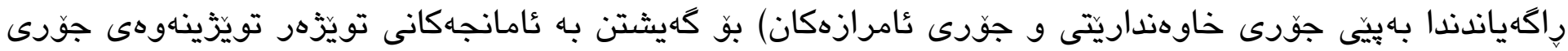
وهسفى و ريّباز (رايِيَّيى) بهكارهيناوه . بو كوكردنهوهى زانياريهكانيش ثُامرازهكانى فورمى (ييّوهر) (مقياس) ى به بهارهيناوه، كه دابهشى كردوه به سـاهر

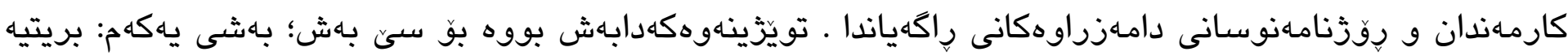

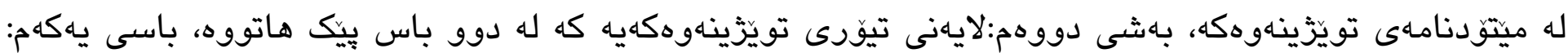

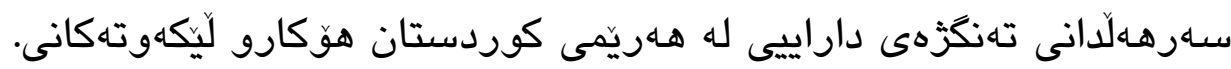
باسى دووهم:سـهرجاوهى داراييى دامـزراوهكانى راكهياندن و تايبهتمهانديه نابوريهكانى.

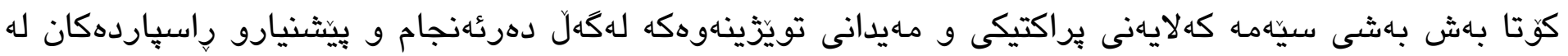
خوَدهكريت .

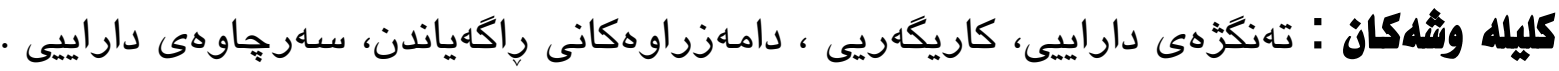


دامهزراوهكانى رِاكهياندن له ئهمرودا له كَّرانكارى بهردهوامدان له رِووى شيّوازى كاركردن،خاونداريتى،بهريّوهبردن

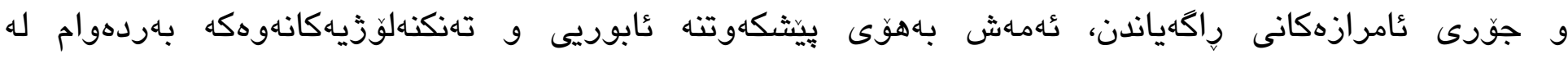

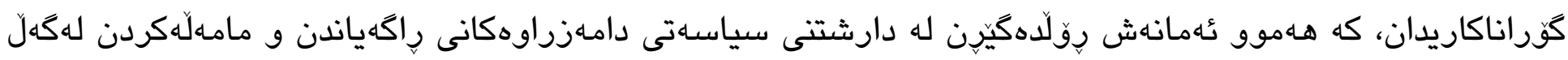

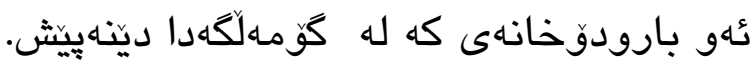

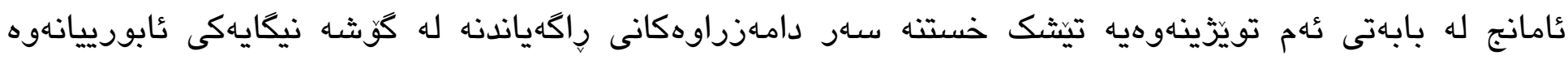

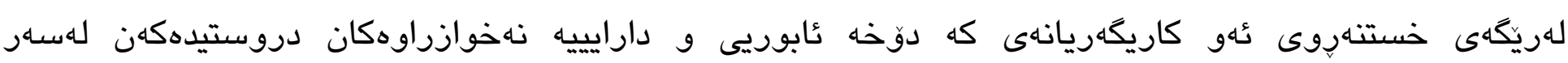

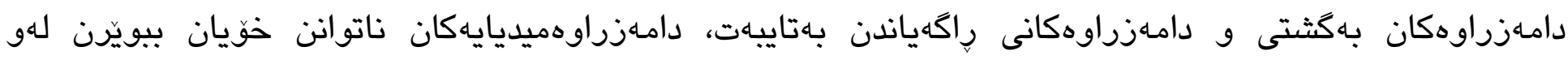

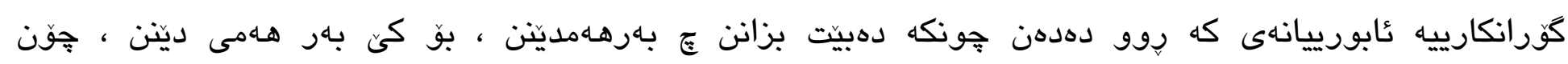
بيثيكهشى وهركيّرى دهكهن.

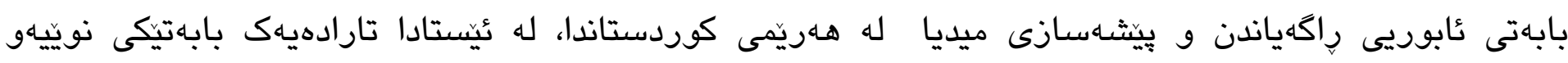

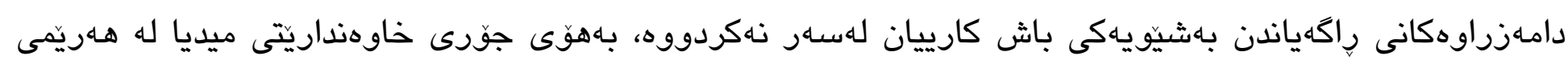

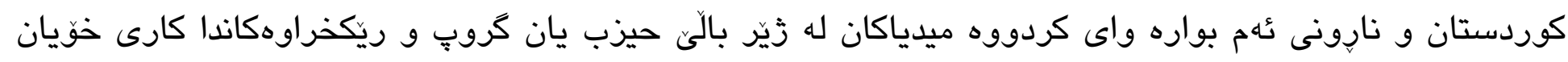

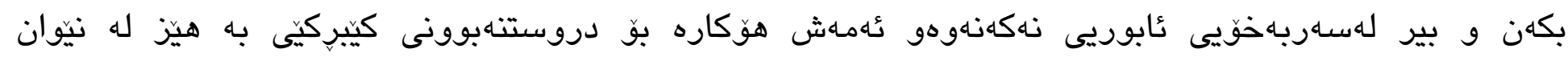

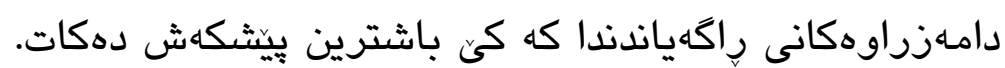

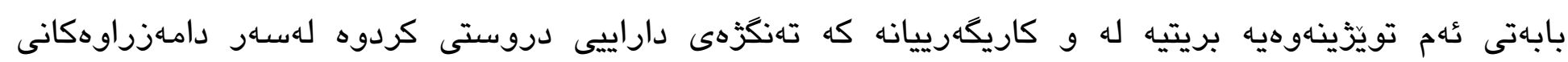

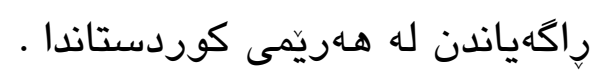

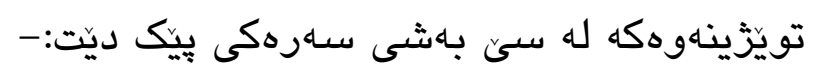

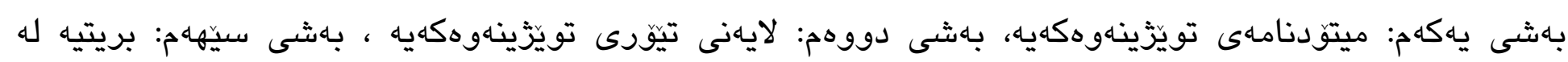

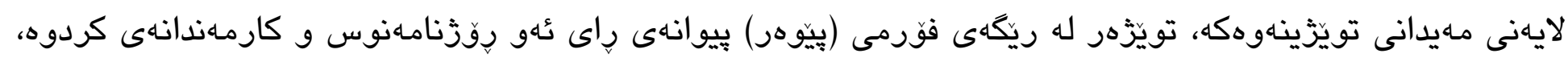

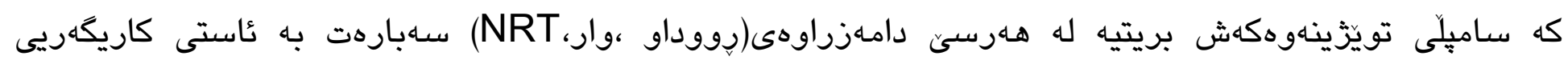
تهنكزهى داراييى له سهر دامهزراوهكانى راكهياندن. 


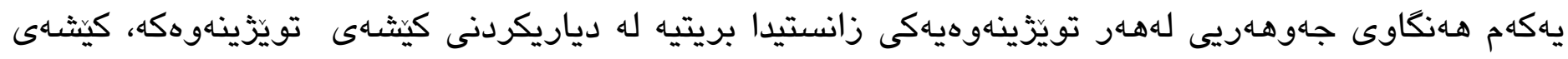
ئهم تويزّزينهوهيه خوى له ودلامى ئهم برسيارانها دهبينيتهوه :-

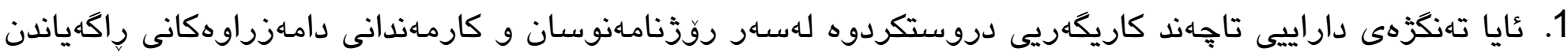

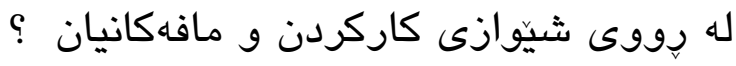
2.

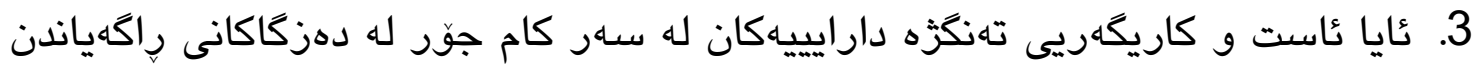
(خوردتر) (بههيزّتره)؟ ( له رِووى خاوهنداريتيى و جوّرى ئامرازهكانى رِاكهياندن )هوه.

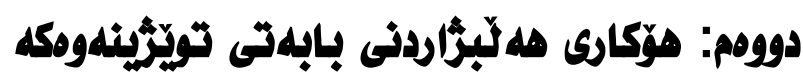

كرنكى و بايهخى ئابورى راكهياند و سهارجاوهى داراييى بو دامهزراوهكانى راكهياندن و بوونى زياد له

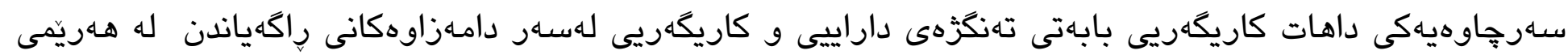
كوردستان بهشيّوهيهكى بارجهاو.

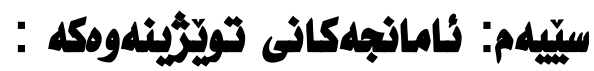

1- خستنه رووى ئاستى كاريكَريى تهنكزّهى داراييى لهسهر ئهو روّزنامهنوسانهى كه له دامهزراوهكانى رِاكهياندا كار

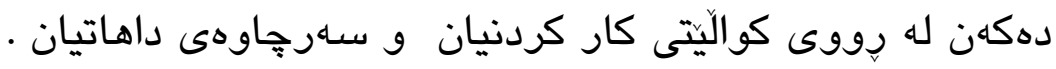

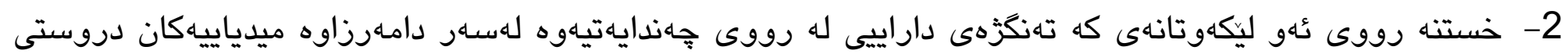
كردوه .

3- خستنهرووى ناستى كاريكهريى تهنكزهى داراييى له سهر جوّرى عامرازهكانى رِاكهياندن.

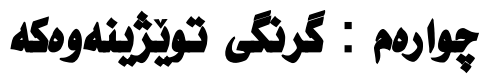

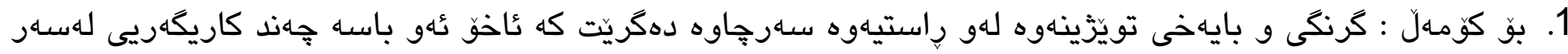

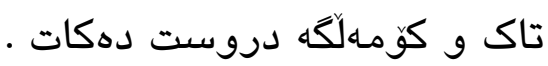

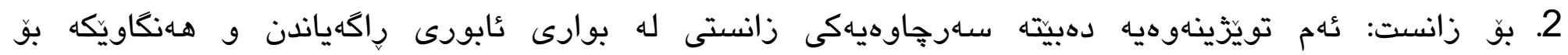

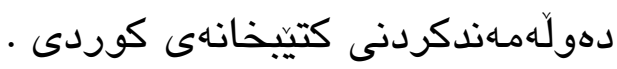

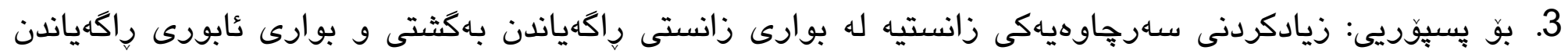

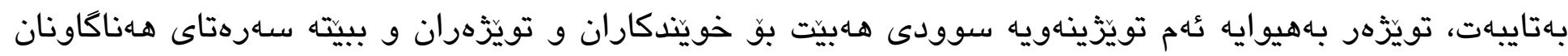

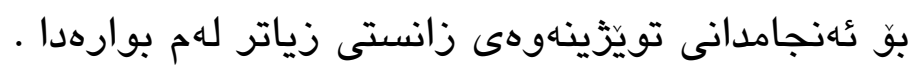




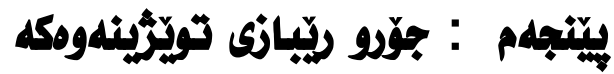

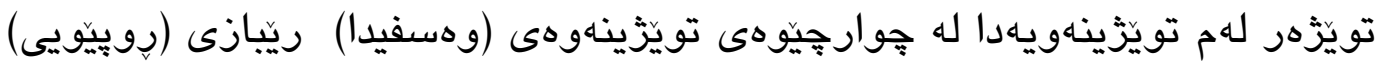

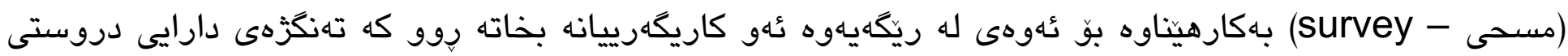
كردوه لهسهر دامهزراوه كانى راكهياندن.

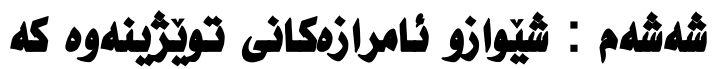

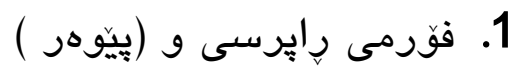

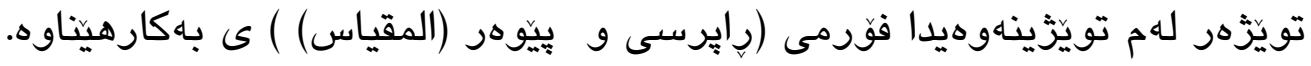

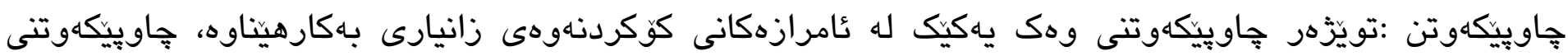

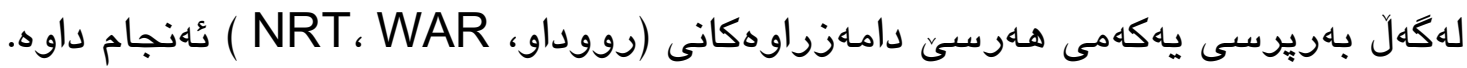

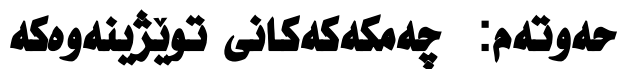

1- يِيناسهىكرداريى كاريكهريى : مهبهست لهو كاريكهرييهيه كه تهنكزهى دارايى دروستى كردوه لهسهر دامهزراوهكانى راكهياندن و سهرجاوهكانى داراييان .

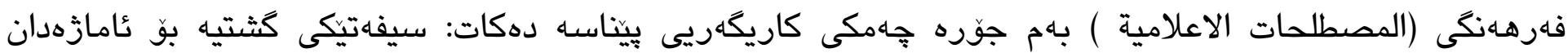

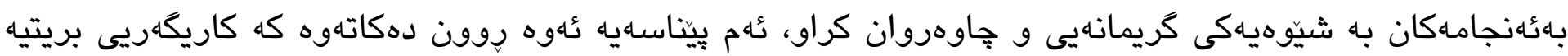

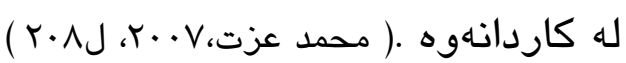

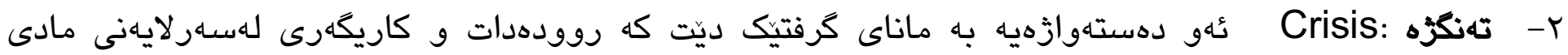

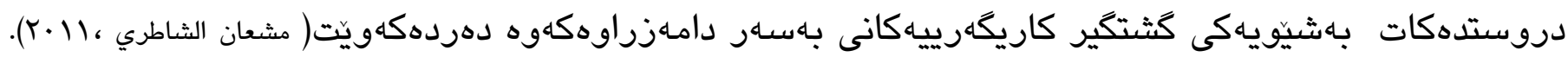
ييناساهى كرداريى تهنكزه: مهبهست له و تهنكزه داراييهيه كه ههريمى كورستانى كرتهوه و كاريكهريى لهسهار

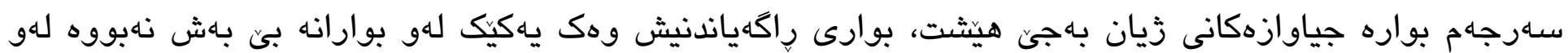
كاريكهرييه . 


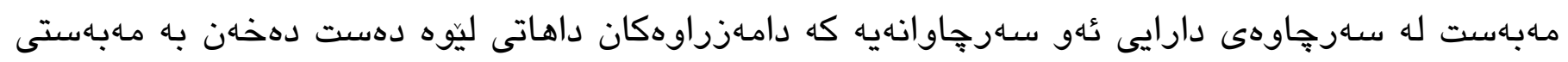

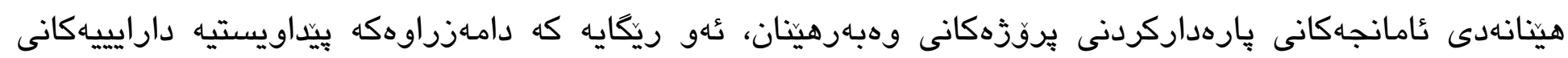

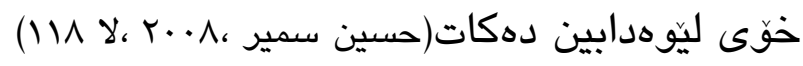

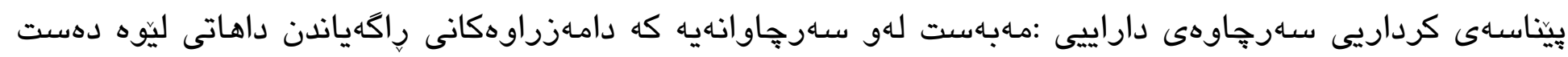
ل دهخهن

$$
\text { 3- دامهزراوهكانى راكهياندن: }
$$

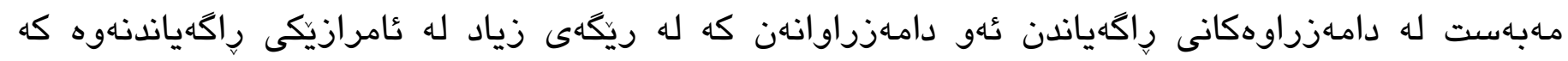

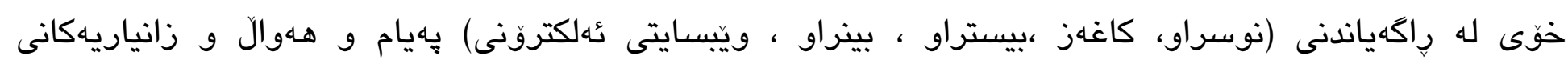
دهكَهيهنيته وهركر.

\section{بلهُ دووم: لايهذى تيوَريى تويَّرئنهومكه}

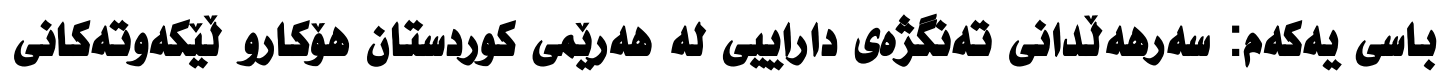

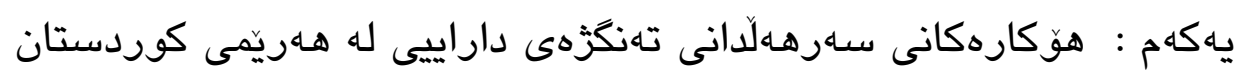

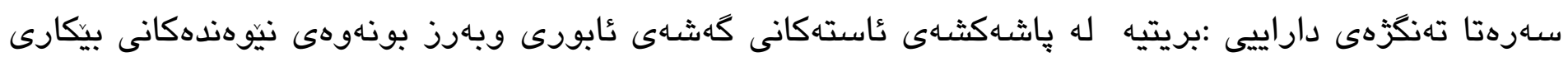

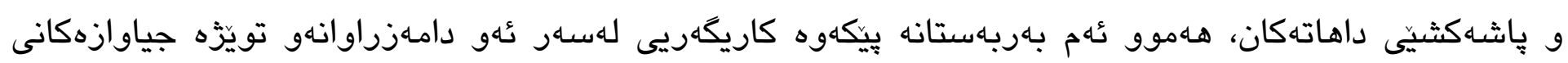

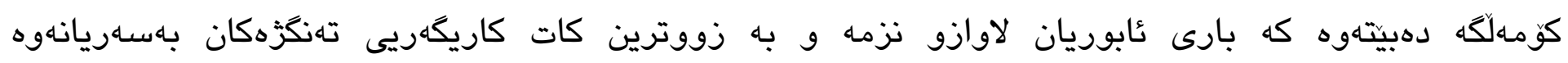

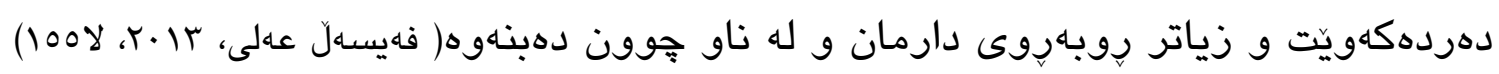

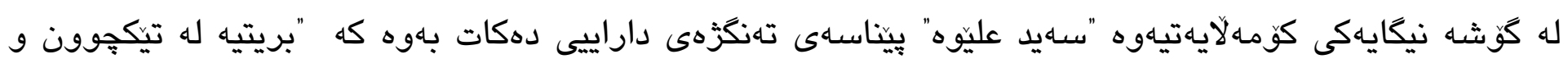

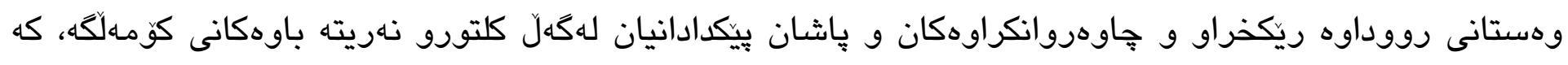

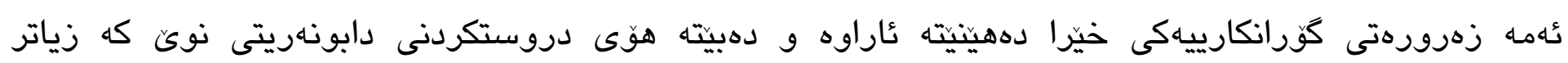

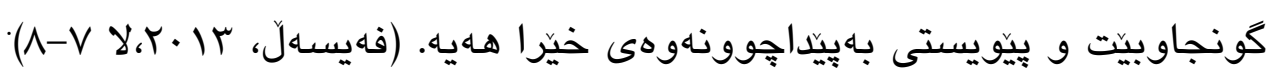

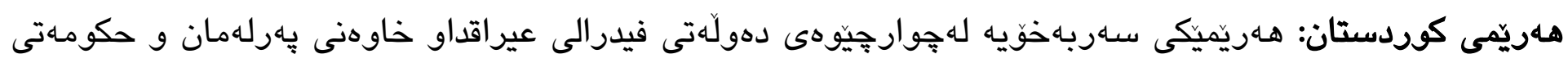

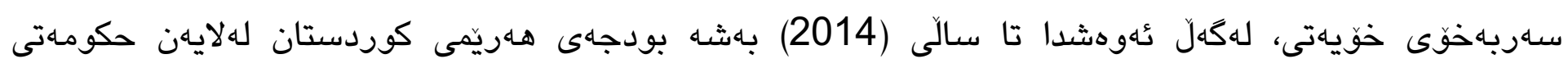

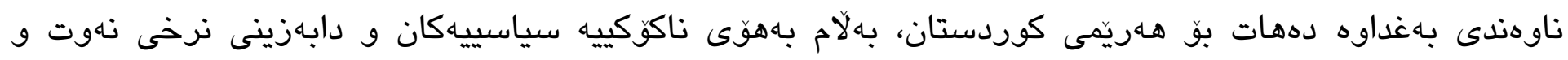

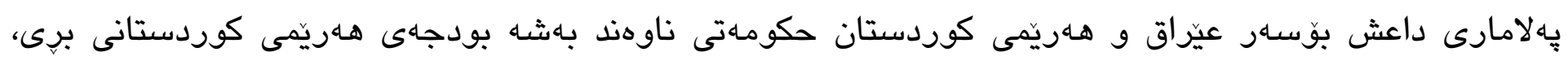

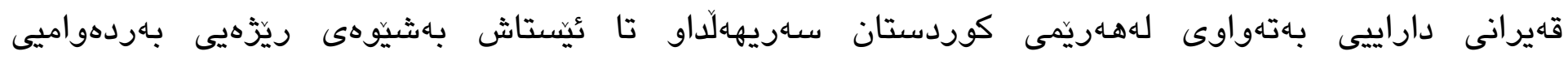

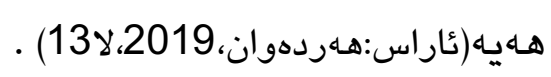




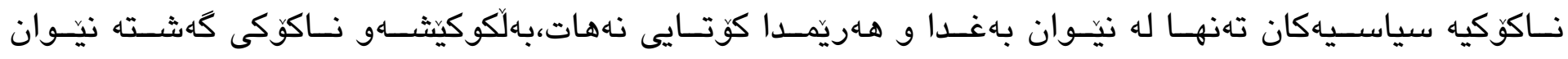

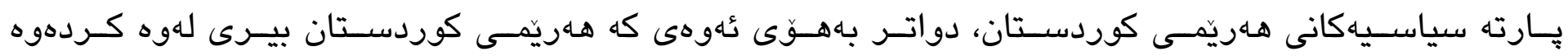

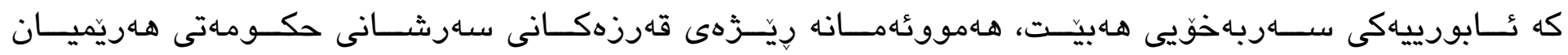

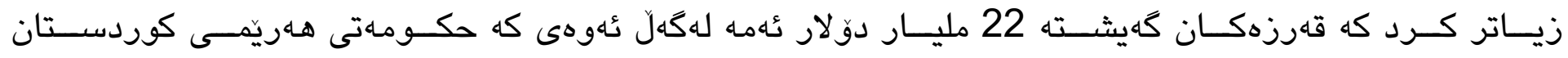

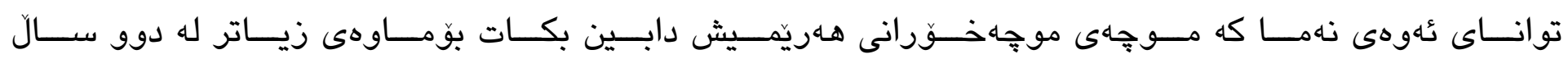

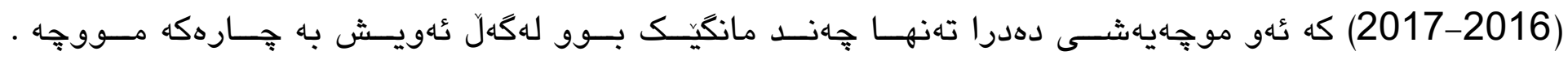
( بامر،العمران (r.17)

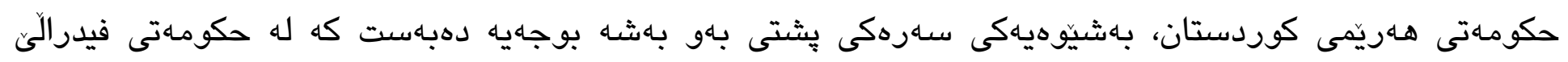

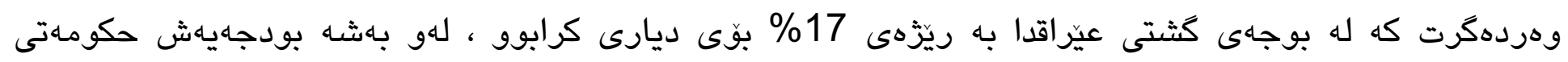

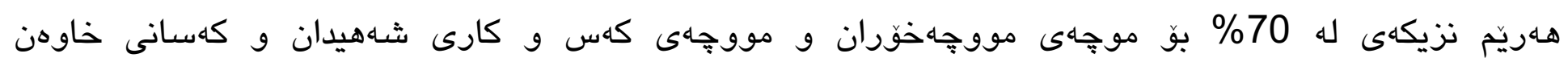

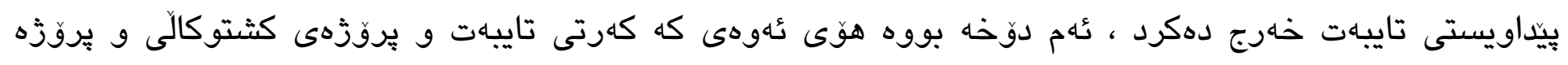

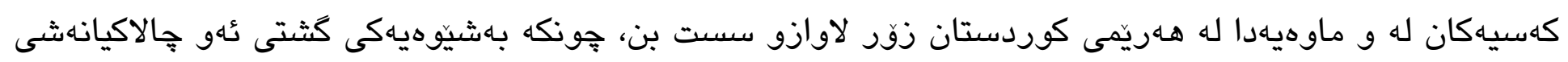

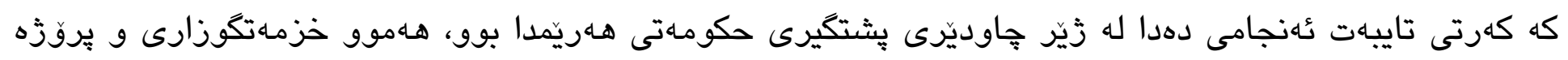

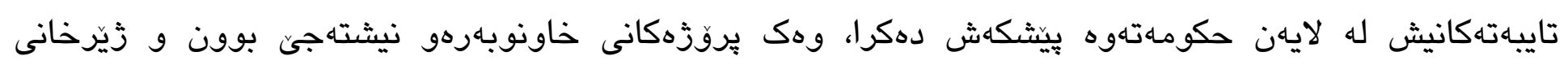

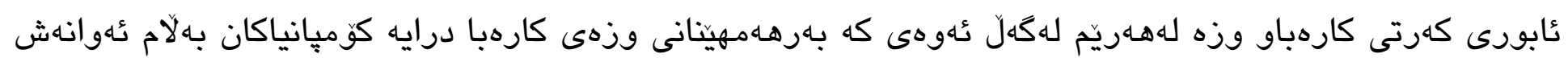
هـهر حكومهت يشتيوانى دهكردن و وزهى بوّ دابين دهكردن ، بوّيه به روودانى تهنكزّهى داراييى ئهم كهرتانه به

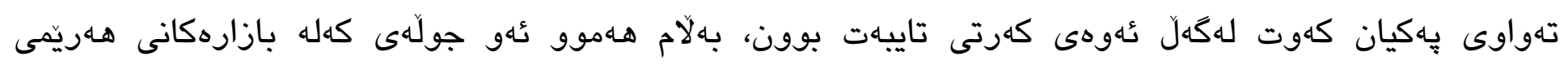

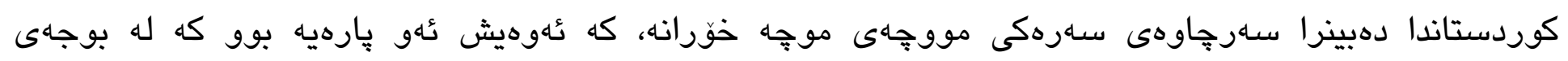
حكومهتى فيدراليّدا بِّ هـهريّمى كوردستان تهرخان كرابوو .

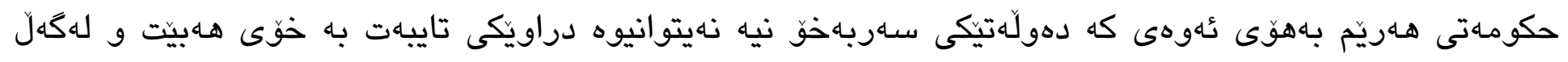

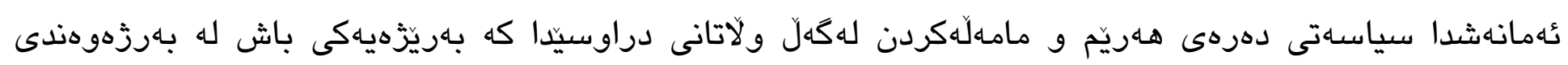

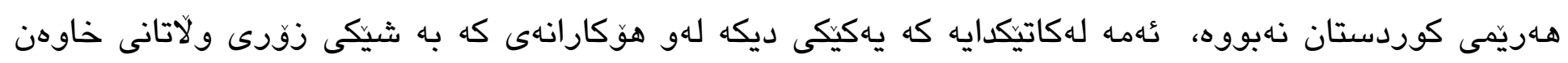

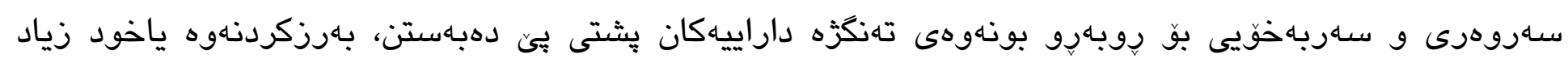

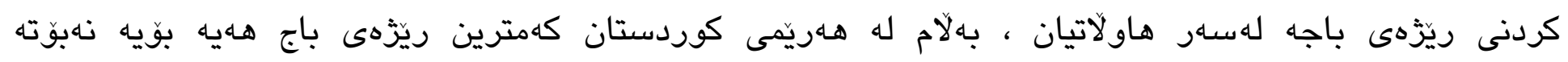

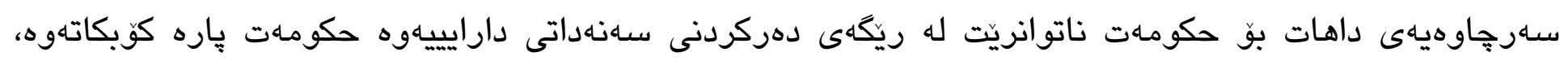

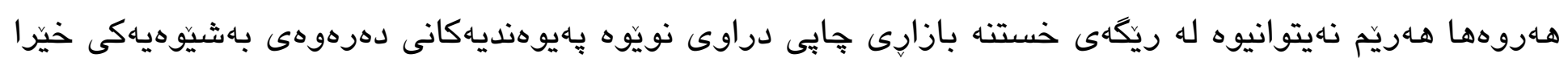

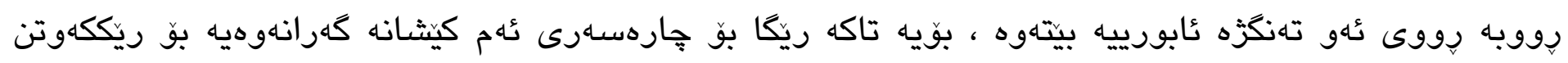

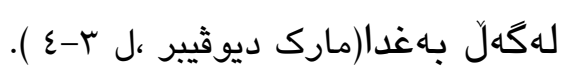

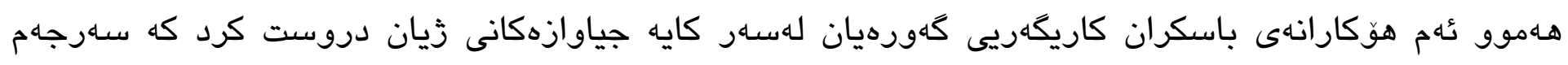

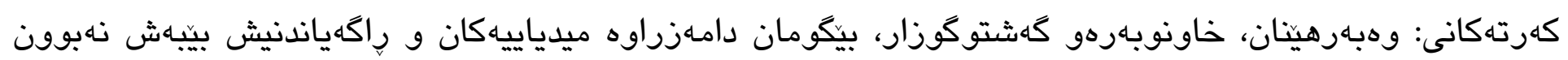




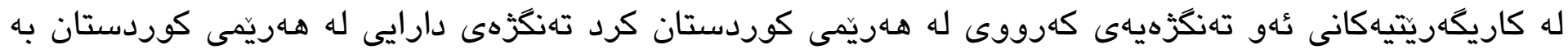

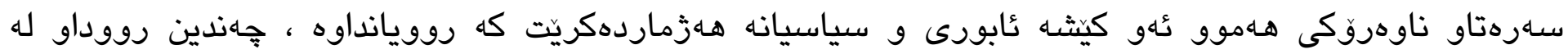

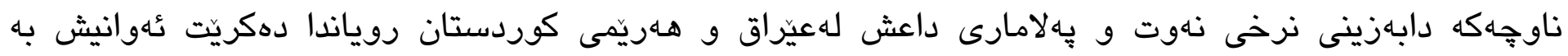

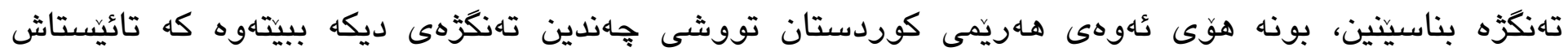

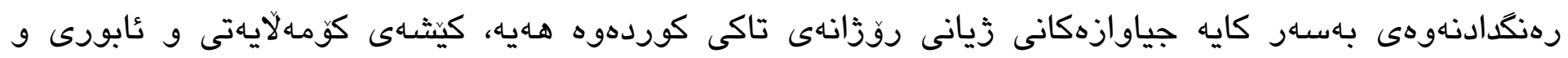
سياسى بهدواى خويدا هيناوه، داعش و يهلاماردانى هـنديك لهناوجه كوردستانيهكان و داكيركردنى موسلّ،

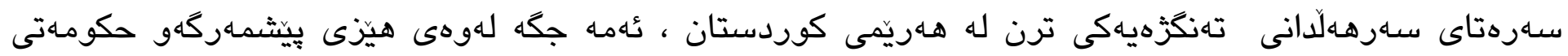

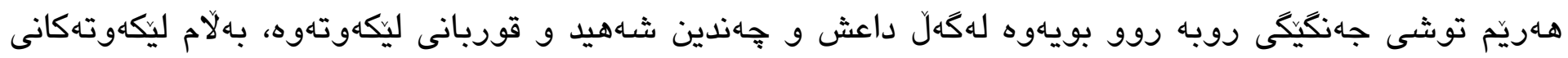

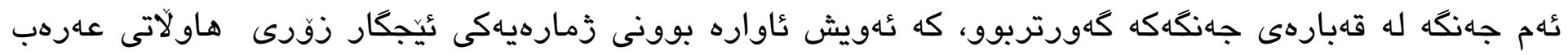

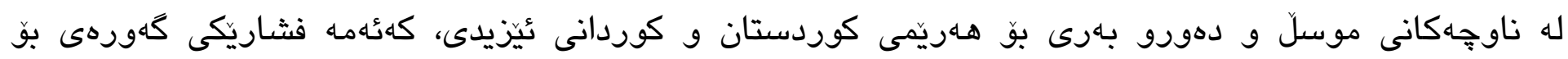
هـريّمى كوردستان دروست كه خُىى له و ساته وهختهدا له دوخيكى نُابورى نهخوازراودا بووه ، بوّيه ئهمه له رووى ئابورييهوه فشارى بّ ومهاتى هـريِّى كوردستان دروست كرد(عامر العمران ).

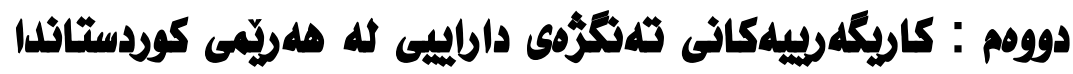

بانكى نيّودهولهتى له دواين رِايوّرتى خوّيدا سهبارهت به كاريكَرى تُهو زماره زوّرهى ئاواره كه روويان له هـريّمى كوردستان كردووه ئامازبهوه دهكات كه هـريّمى كوردستان به هوَى ئهو زماره زوّره له ئاوارهى سنورى

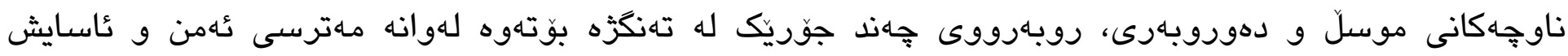

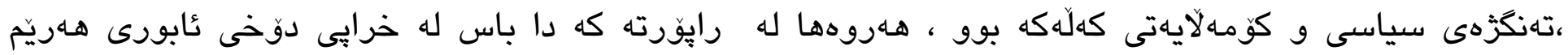
دهكات بهتايبهت كئه قهرزانهى كه له سهرى كهلّكه بووه ،كه به زياد له 22 مليار دولار مـزهنده دهكريت، رايّورتهكه ئامازهى بهوه داوه زياد بوونى قهرزهكانى هـريّمى كوردستان بههوى دابهزينى نرخى نهوتهوه، بووه هوَى دروست بوونى عالِّزى و يشيّوى و هاتنه سـه رشاهقامى خهلك و دهربرينى نارهزايى لهلايهك و كوجكردنى

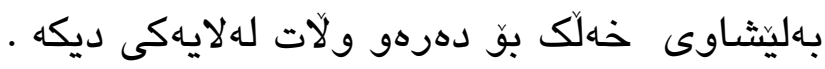

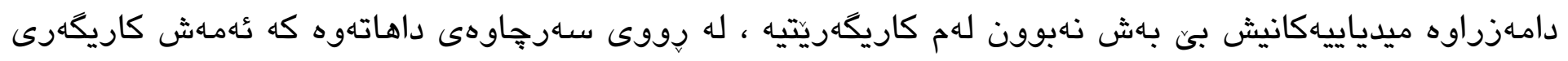

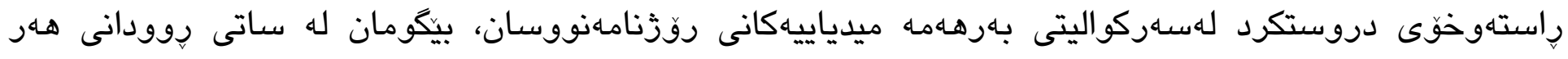

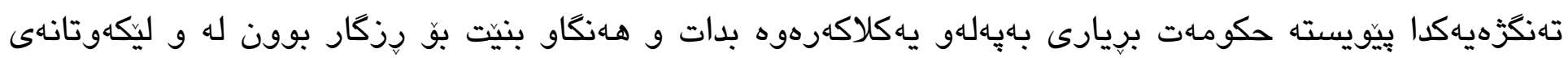

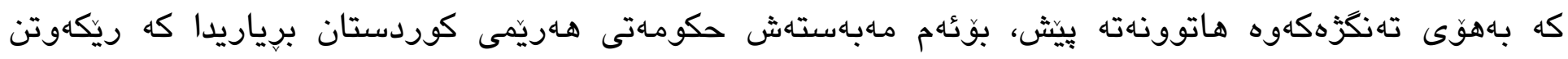
لهكَل بهغدا بكات، بهمهبهستى رِووبه رِوو بونهوهى ئهو تهنكزه دارايييهى كه له هـهيّمى كوردستاندا رِوويداوه،

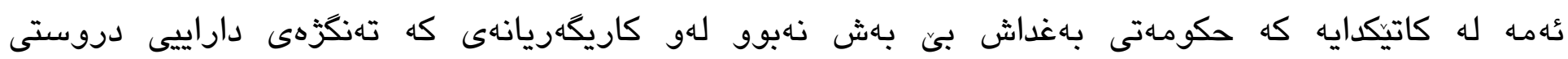
كرد) (. r. IV،Abbas’ Noori 


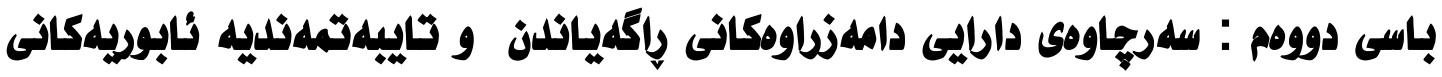

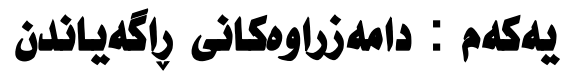

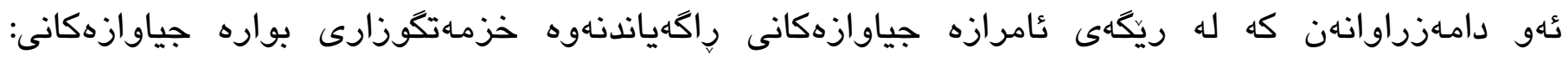

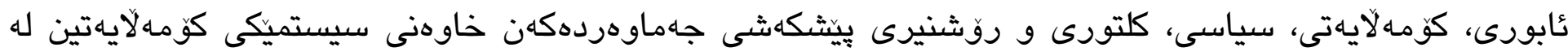

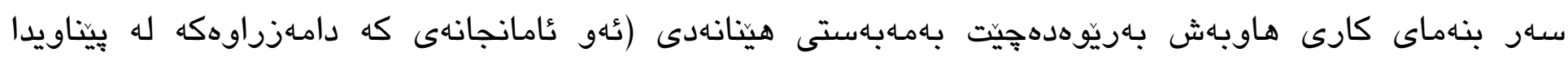

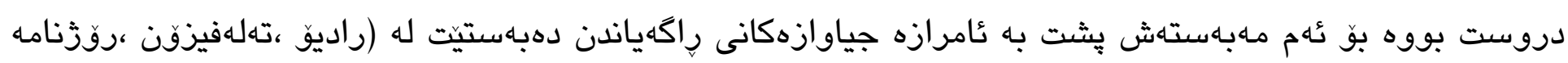

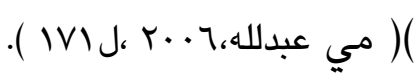

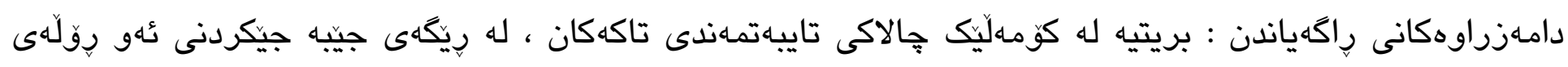

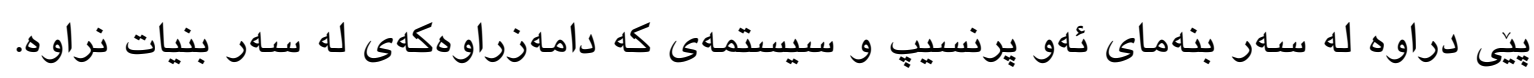

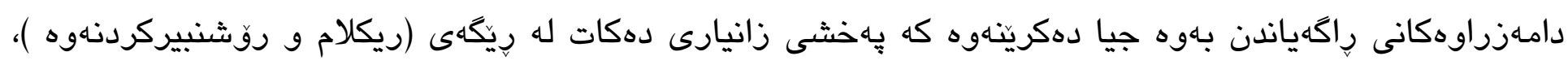

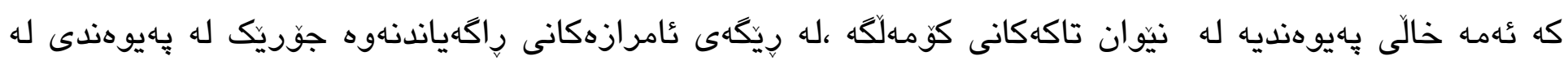

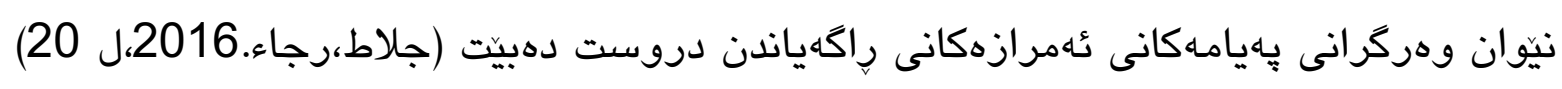

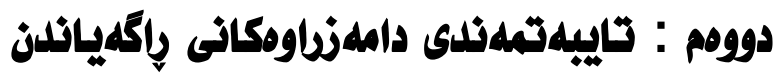

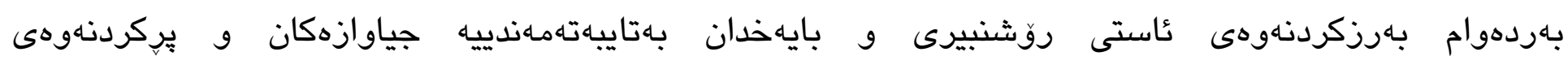

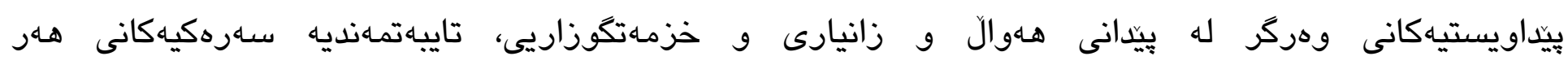

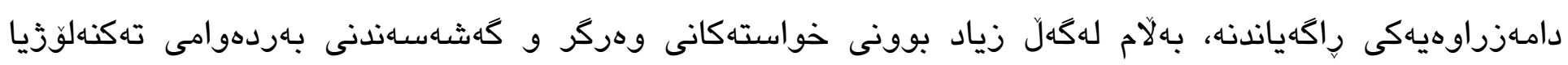

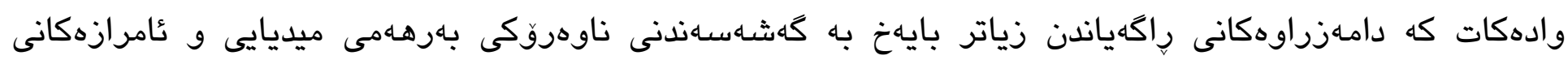

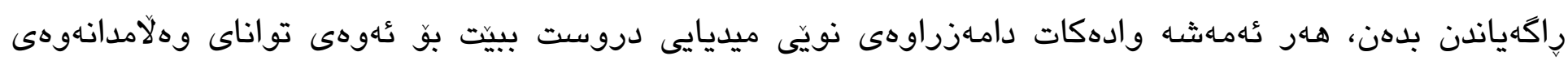

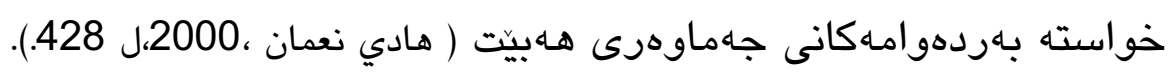

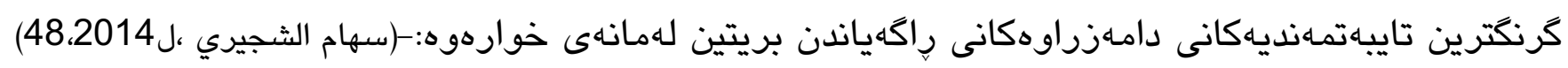

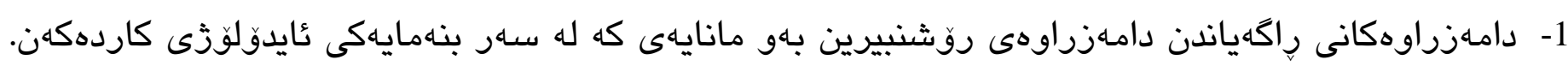

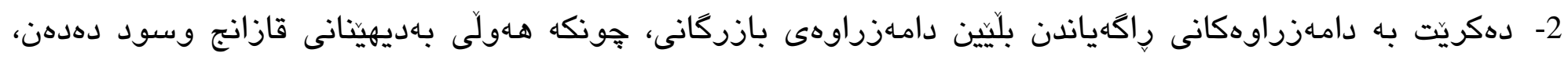

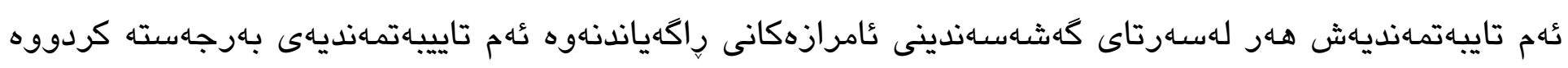

3- تئه كارمهندانهى كه له دامهزراوهكانى راكهياندا كاردهكهن به يلهى يهكهم دهبيّت له رووى پيشهاييهوه

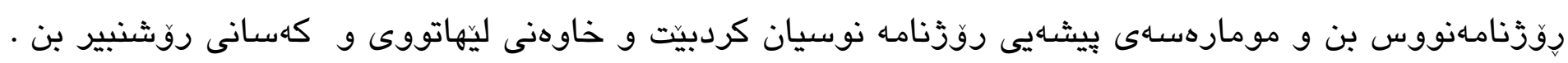

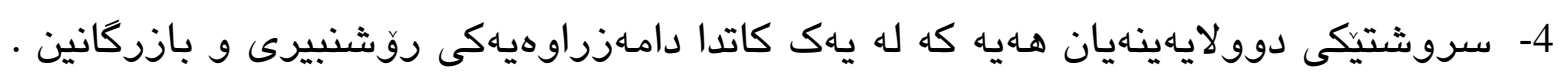




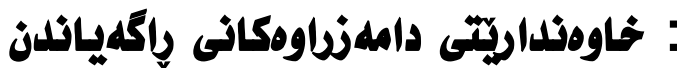

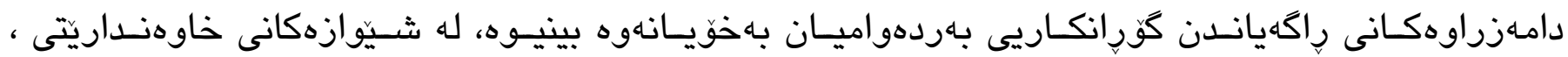

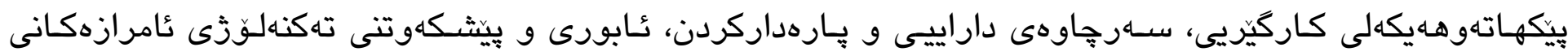
راخهياندن وبهرهـهمينان.

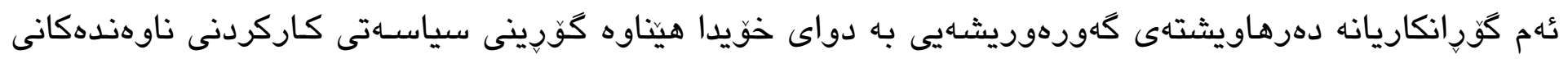

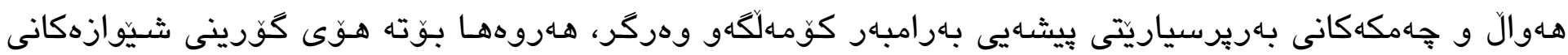

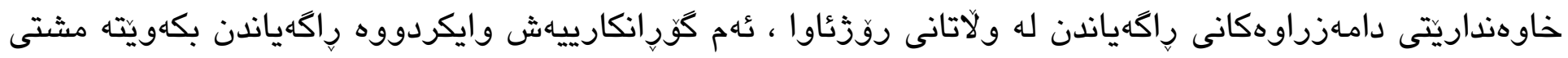

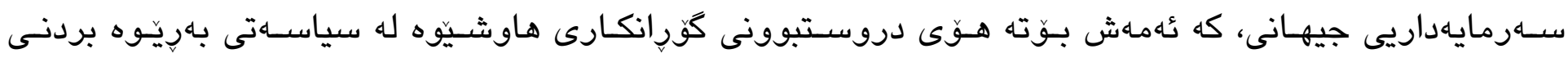

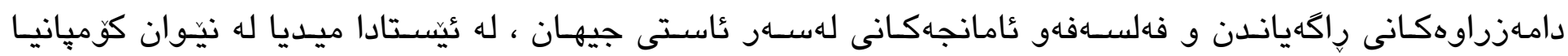
كَهوركـان و دامـازراوه زهبهلاحهكانى دونيـادا دابهش بـووه ، بـويه دامهزراوهكانى راكهياندن له ئيسـتادا به بـلهى يهكهم بونهته قهوارهيكى عابوريى. (سهام الشجيري ،ل 159، 2016 ).

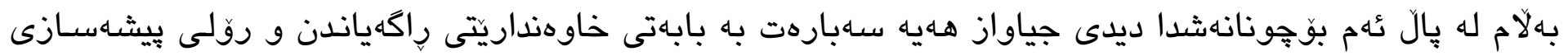

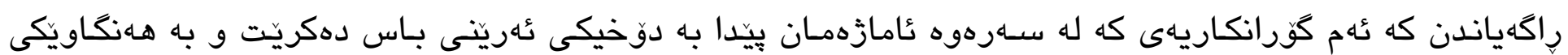

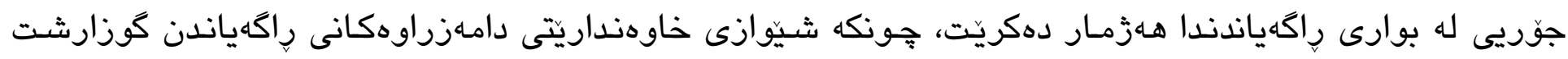

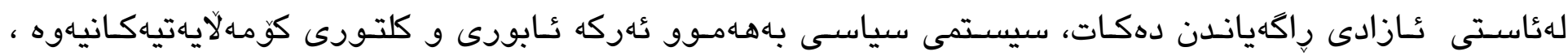

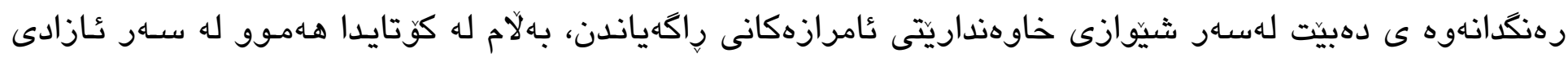
راكهياندن كوكن ، خاوهنداريتتى دامهزاوهكانى راكهياندن برى ئهو عازاديه دياريدهكات (ابراهيم عبدلله ، 2007،ل348).

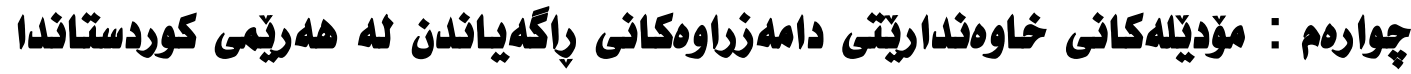

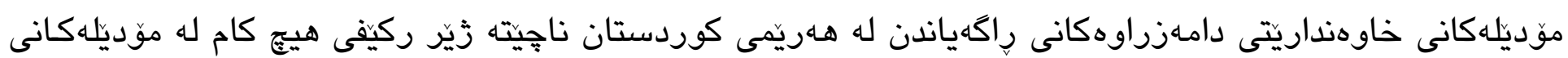

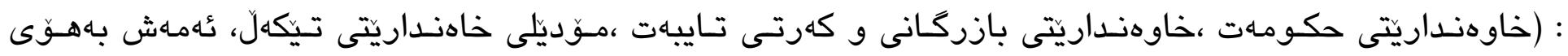
تايبهتمهاندى ردوشى هـهريمى كوردستان لهروى سياسى و عابورى،له لايهك و نهبوونى ديدكايهكى عاشـكراو روشـن

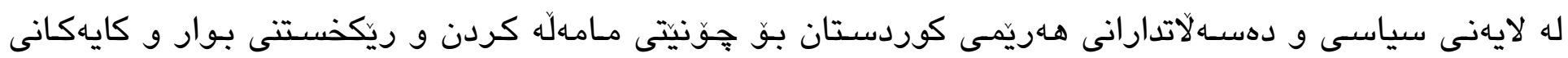

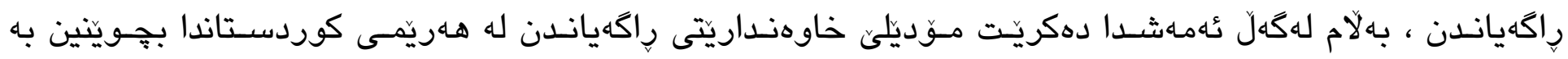

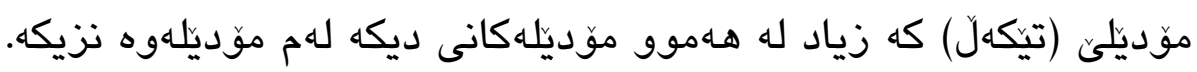

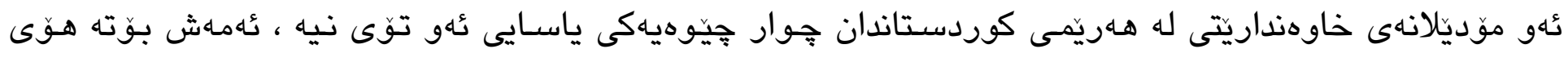

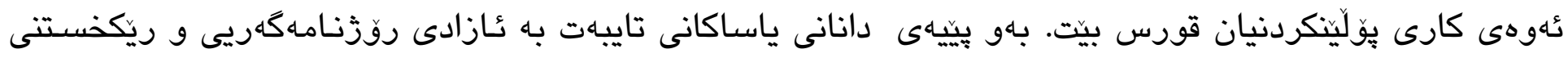

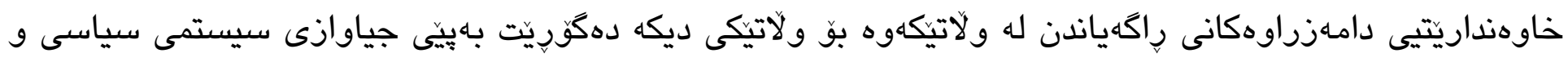
بهها ئيتيكى و نهريته كومهالآيهتيهكان .

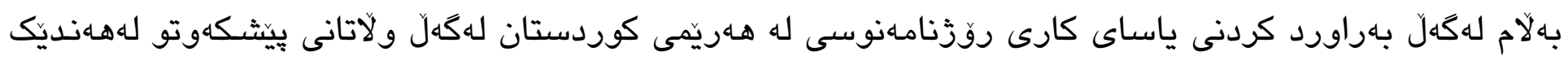

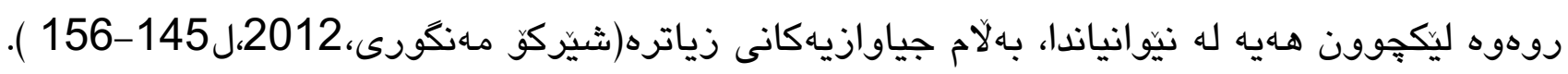


لهميانهى جوارجيّوهى ياساى كارى ميدياكان ،لهكاركردنى دامـرزراوه ميديايهكاندا دوو جوّرى كرنك له دهزكَاى

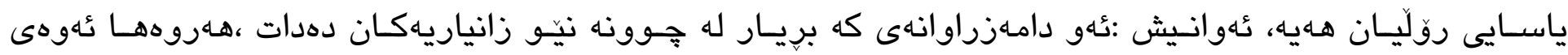

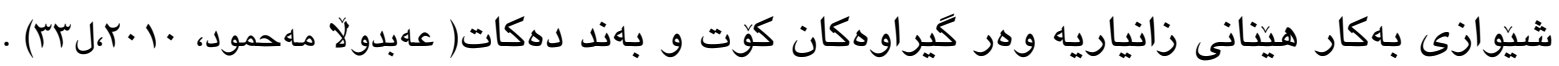

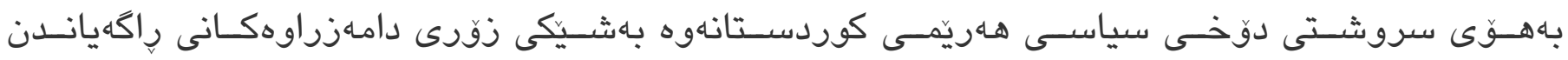

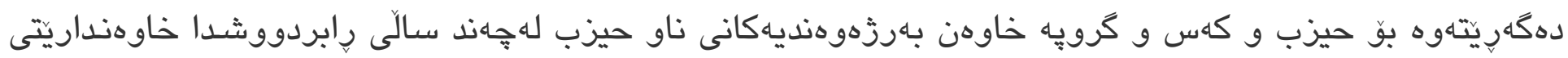

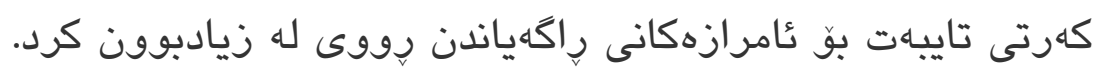

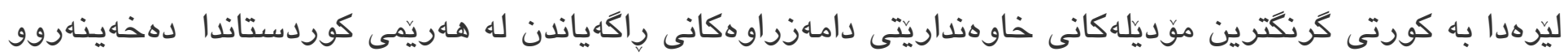

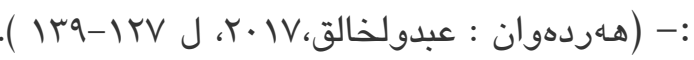

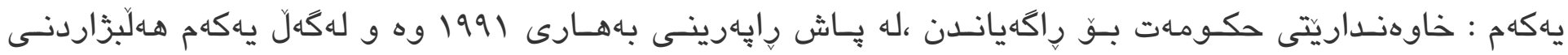

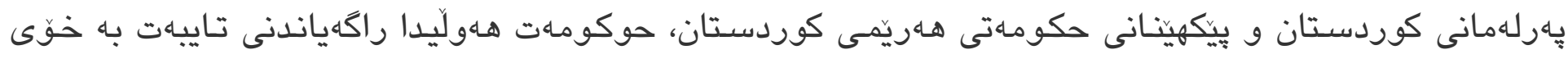

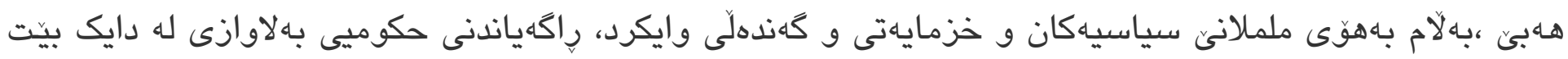

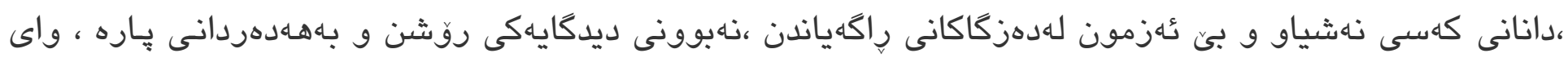
كرد راكهياندنى حكوميى لاواز بيّت ،ئهو راكهياندنه حكومييانهى تائيسـتا له كار كردن بـردهوامسن ،وهك مـالِيهره فهرميهكانى حكومـهت و وهزارهتهكان و يهارلهمان و رِاديوّو تهلهفيزوّنهكانى سـهر بهوهزارهتى روشـنبيرى و ناخو،

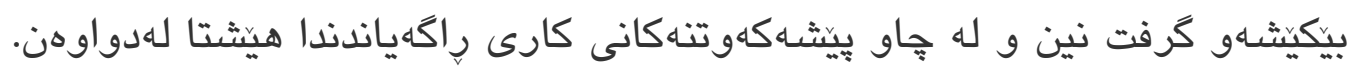

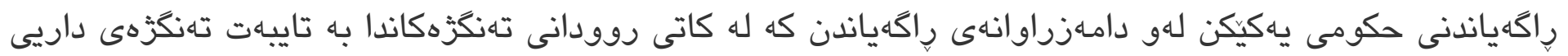
روبهروى زورترين زيان دهبنهوه بوّنمونه رِاديوّ و تهلهفيزونى نهوروز كه سسهر بهوهزارهتى روشنبيرى بوون به

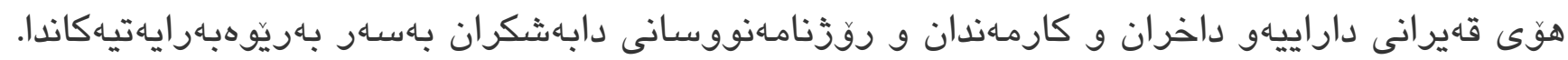

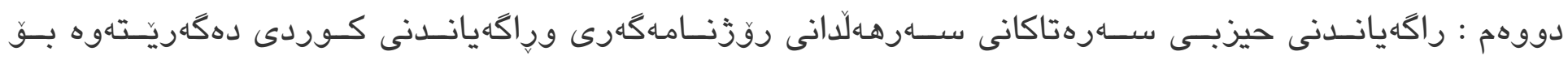

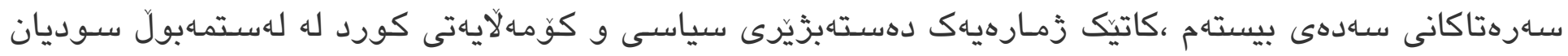
لهو كرانهوه سياسياءى دواى 19.19 وهركرت .

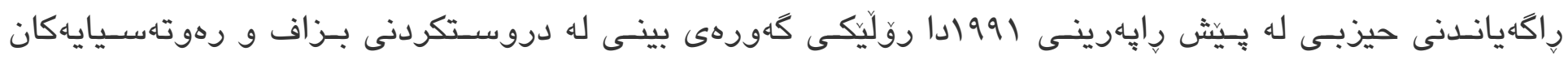

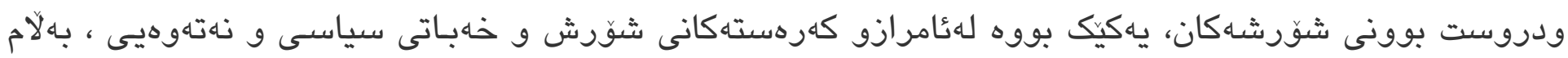

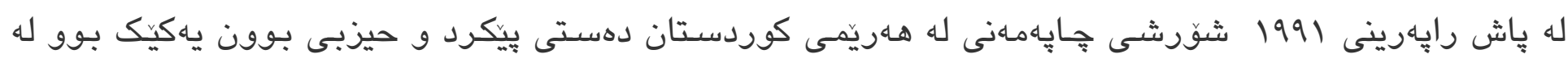
سيما ديارهكانى عُهوروّزنامانه.

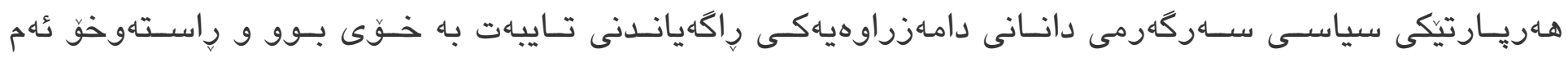

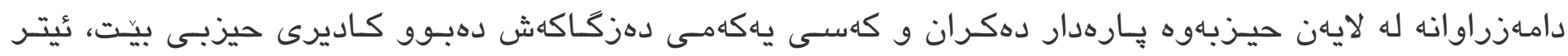

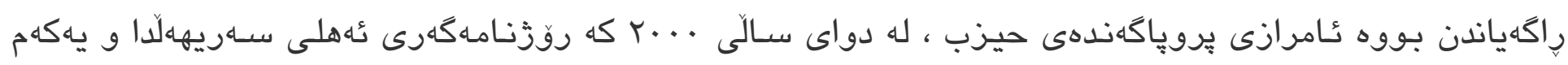

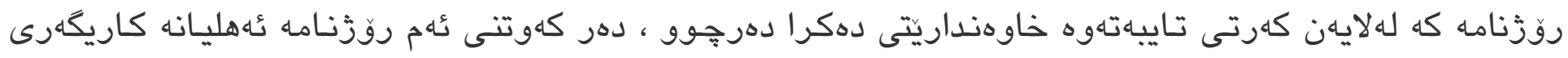
للهسار كهمبونهوه تيرازى روزّنامـه حيزيهكان كرد. 


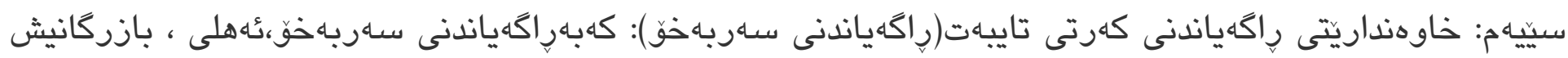

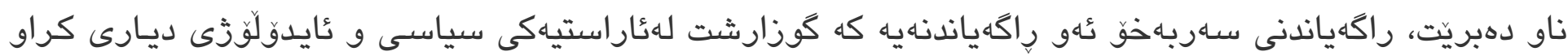
ناكات، كرايهوهيه بـرووى بوّجوون وئاراسته جياوازهكاندا.

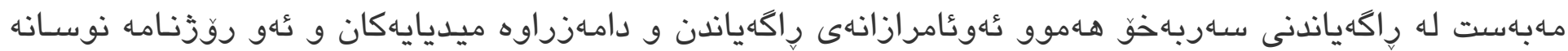

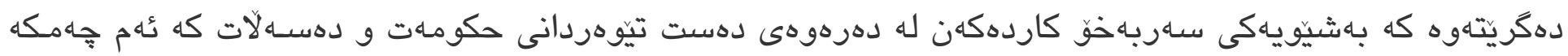

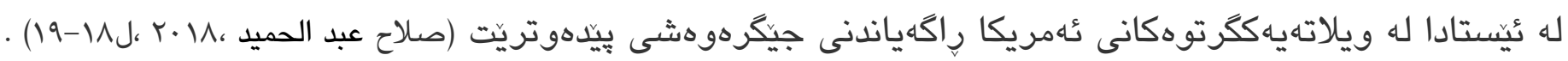

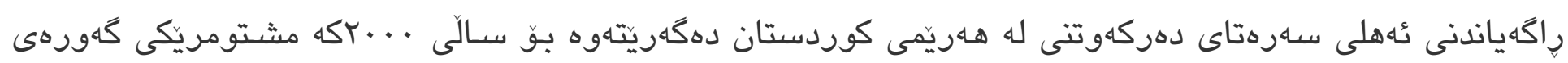
له بوارى رِاكهياندندا به دواى خوّيدا هينا. هوارهم: راكهياندنى بازركانى ،بهاهيكه لهو راكهياندنهى كه لهلايهن كهرتى تايبهتهوه خاوهنداريتى دهكريت ،جياوازى

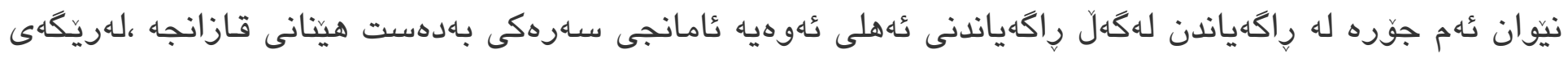

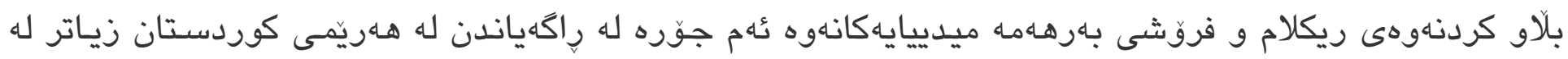

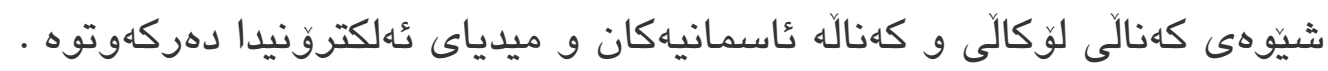

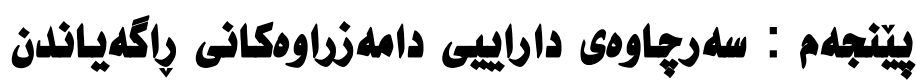

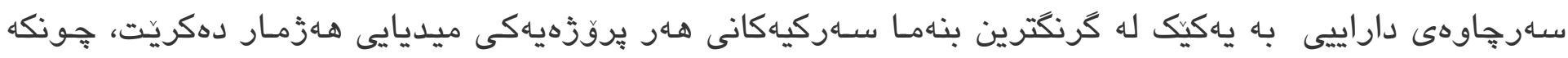

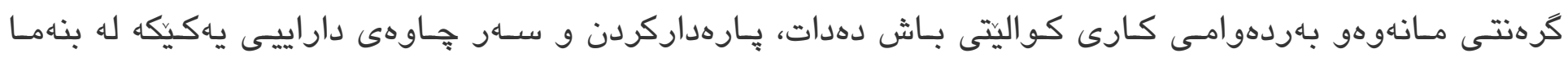

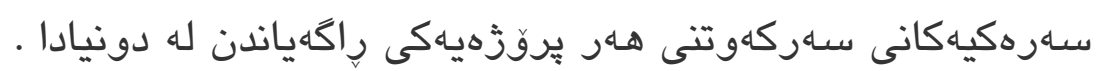

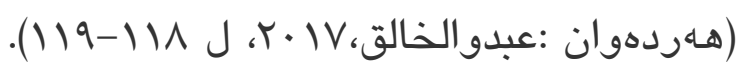

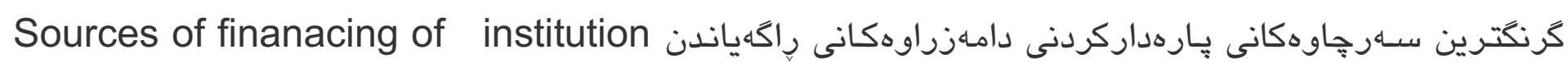
.media

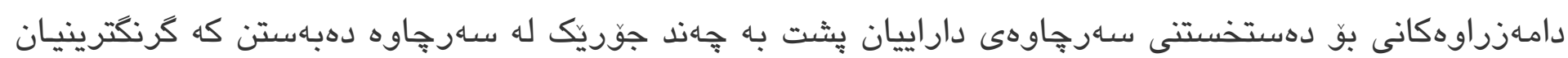
بريتين لهمانهى خوارهوه :1

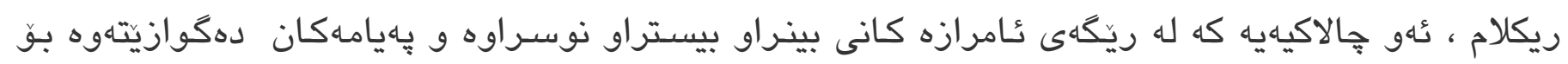

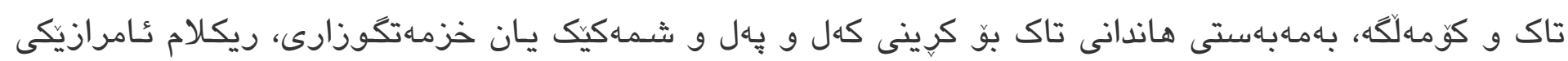

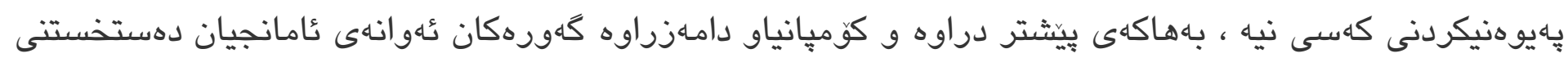

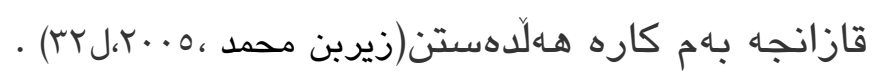

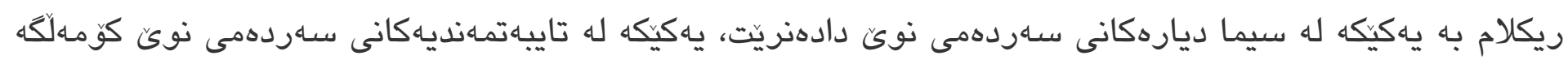

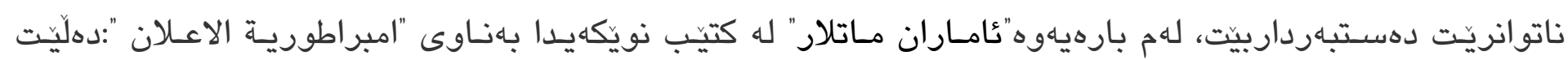

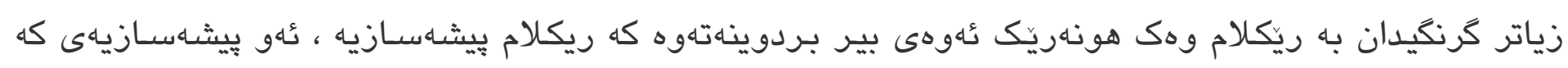




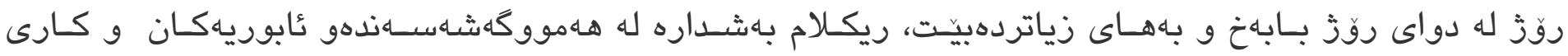
دامـزراوه جياوازهكان.

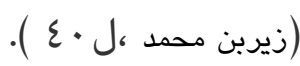

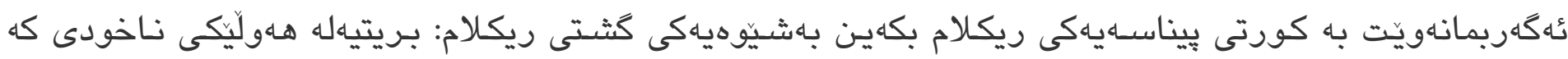

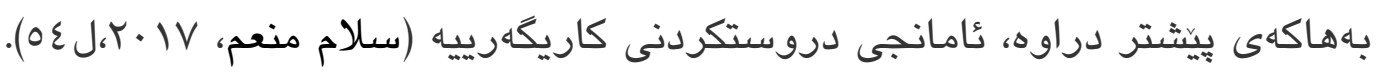

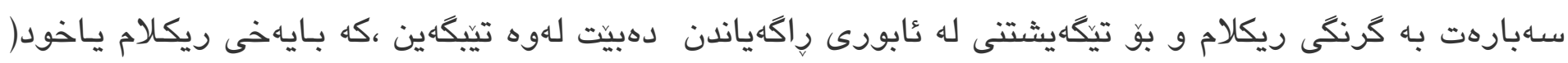

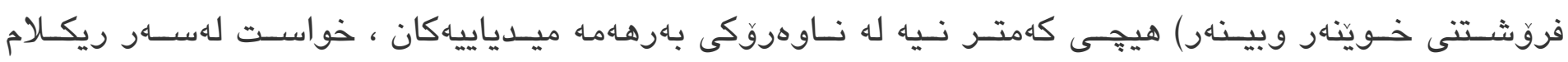

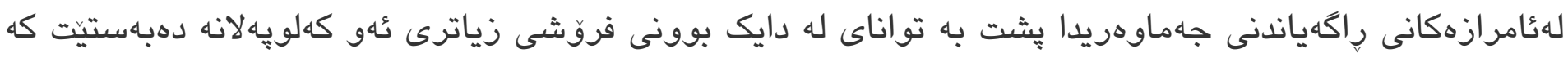

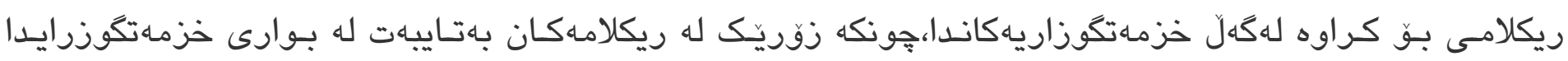

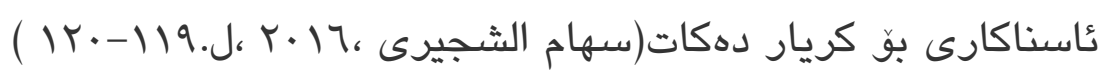

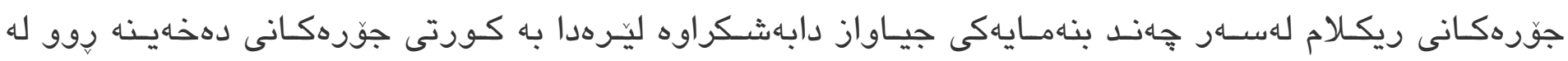

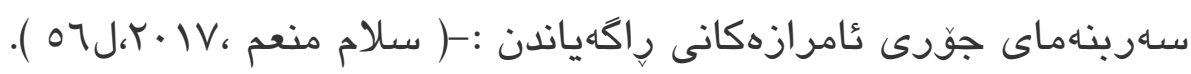

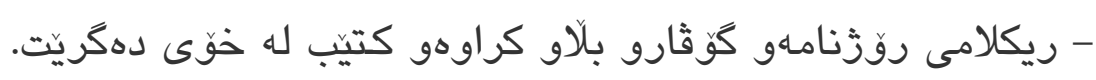
- ريكلامى راديّو تهلهفيزون و سيناهما. - ريكلامى ئهلكترونى و نيمـالْ. 2 - فروشتخى بهرنامه وبهرهـمهـ ميدياييهكان :

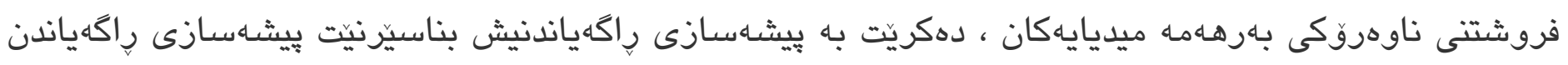

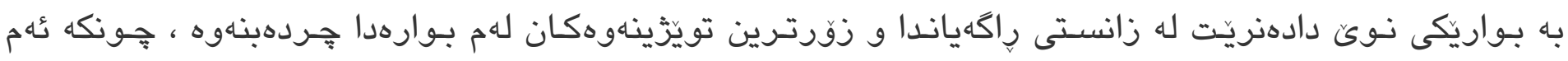

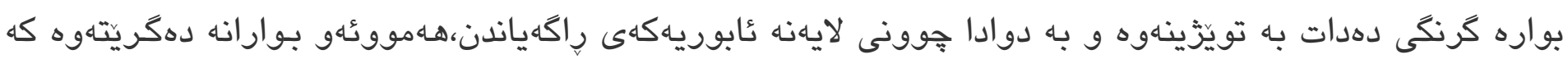

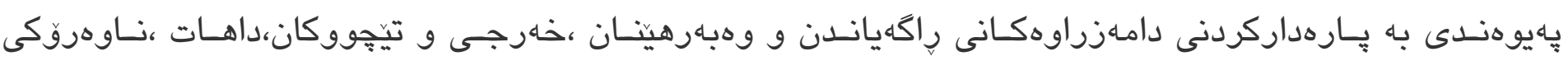

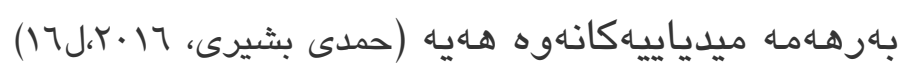
3 - يشتكيرى حكومهت و كهرتى تايبهت:

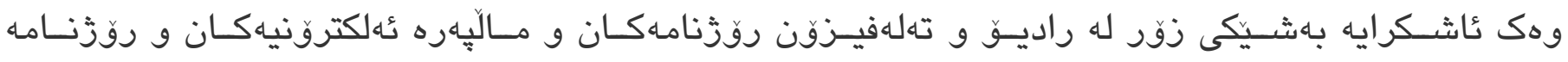

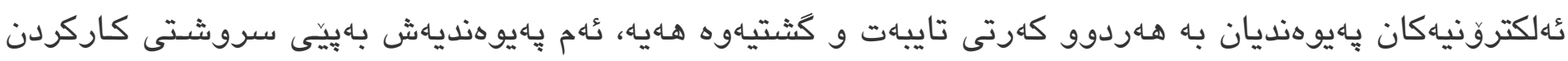

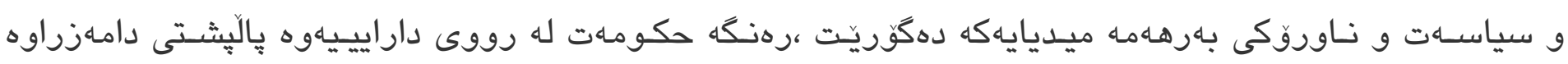

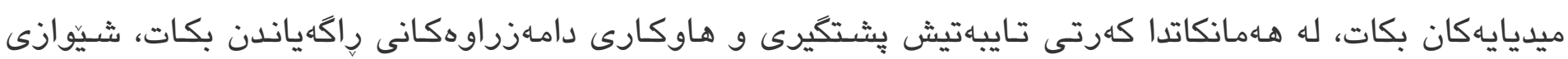

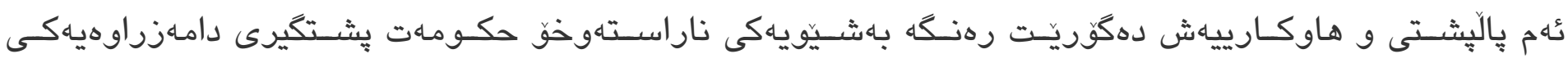

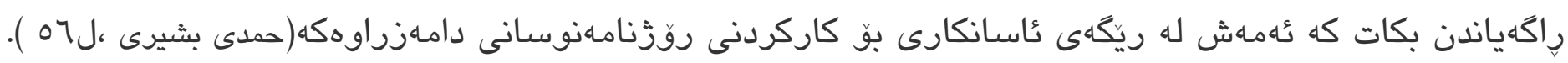




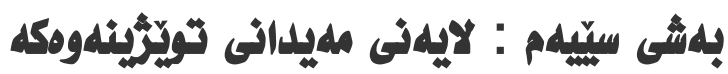

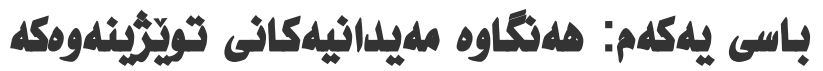

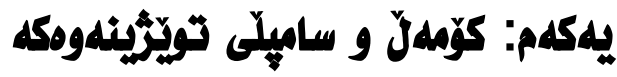

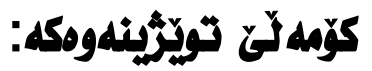

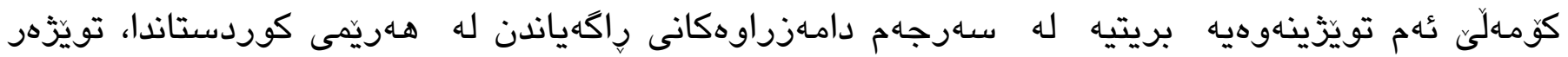

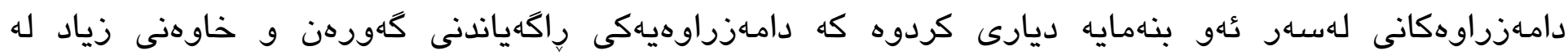

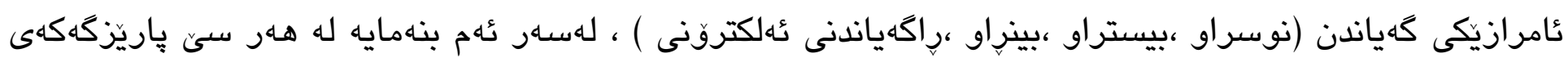

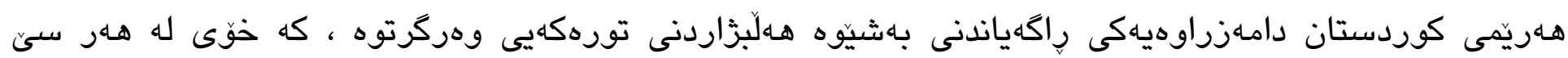

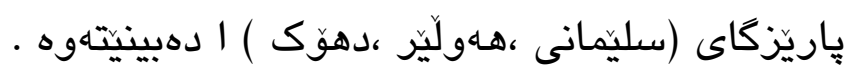

\section{r- ساميلى تويَّرينهوه كه}

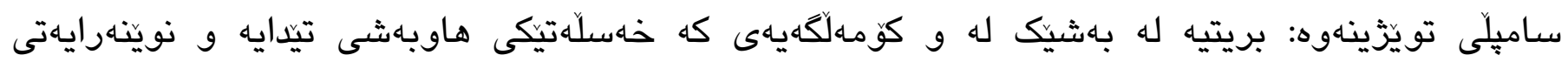

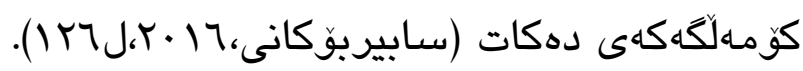

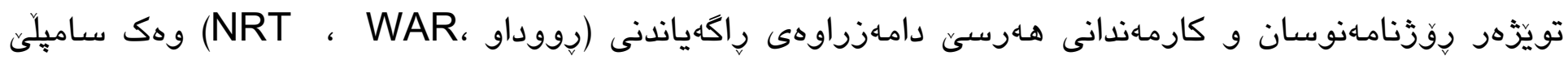

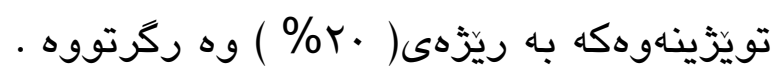

\section{دووم : :إستى و جيلكيريى :}

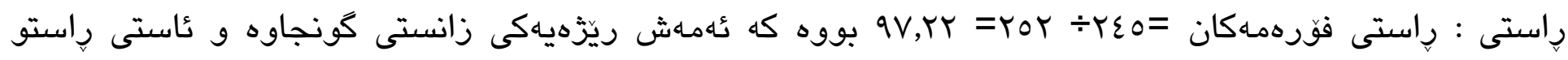

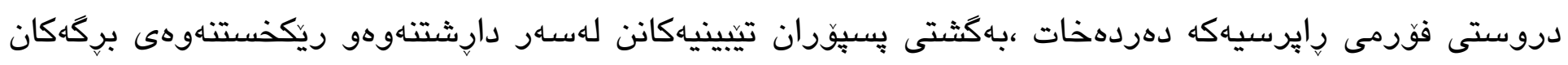

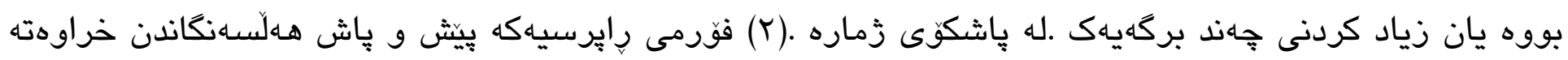

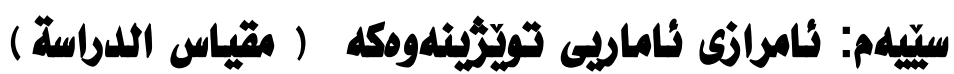

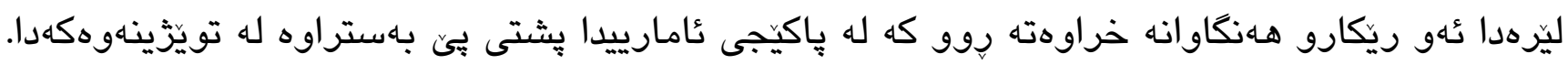

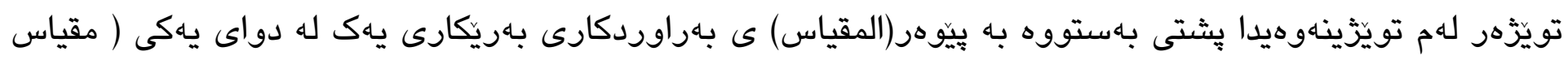

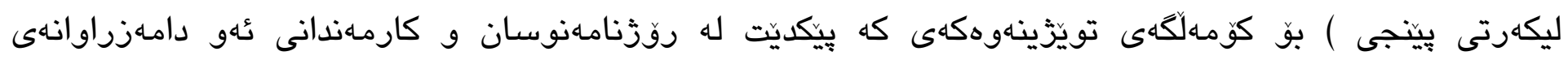

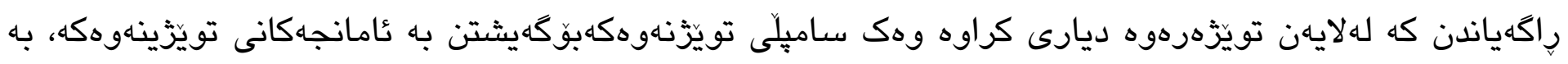


بهرنامهى ئامارى (S.S.S.S فورمهكان بهالكراونهتهوه .بق شيكردنهوهو دهرهينانى ئهنجامهكان سود لهم كرداره

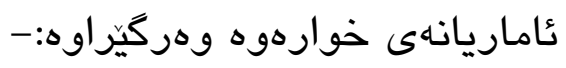

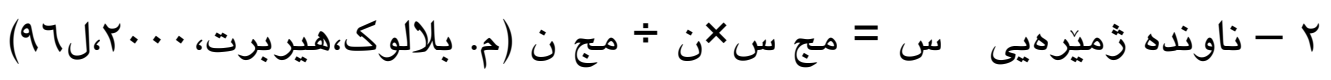

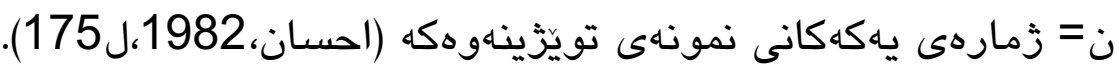

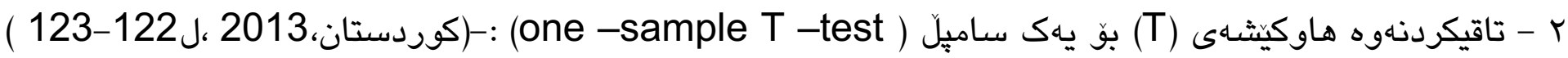

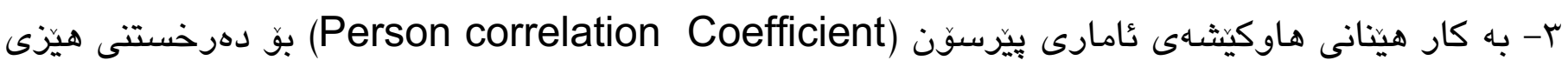

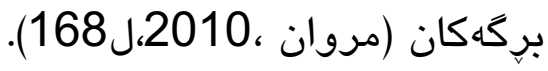

\section{باسى دووم : خستثله يووى تله نجامهكان}

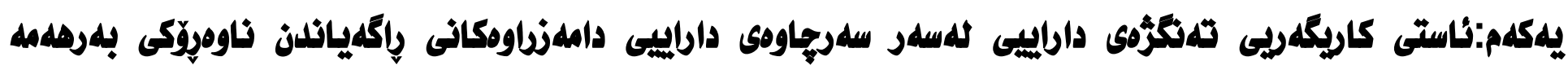
ميلياليبهكانيان.

1 - خستنه رووى ئاستى كاريكهريى تهنكزهى داراييى لهسهر دامهزراوهكانى راكهياندن ، له ديدى روزنامهنوسان

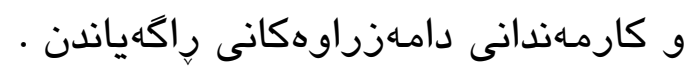

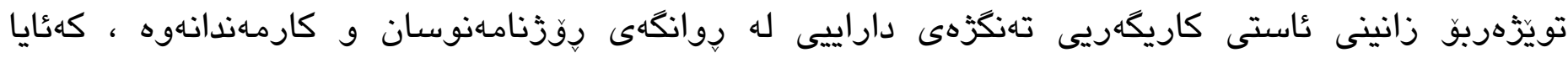

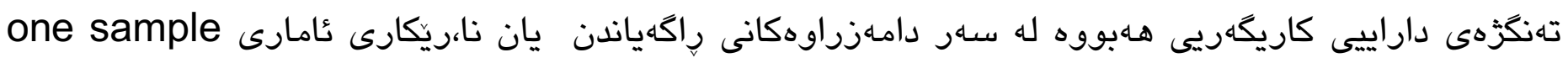

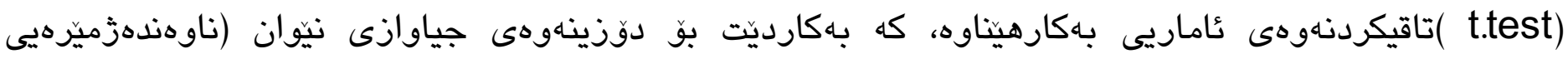

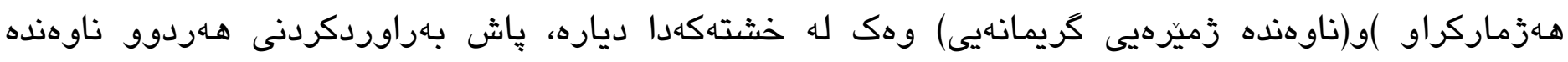

زميَردييه

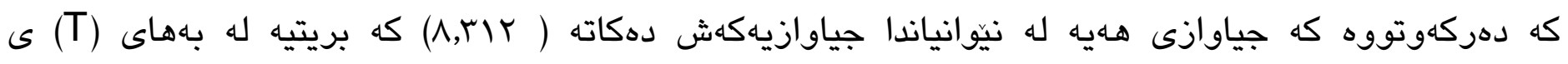

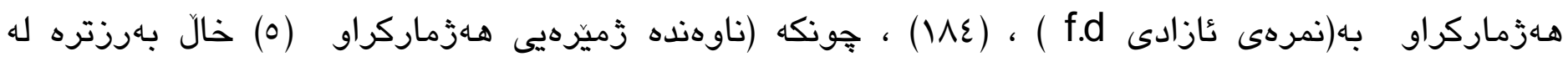

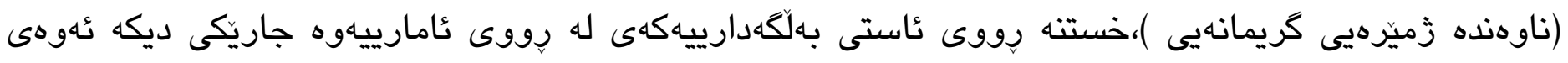

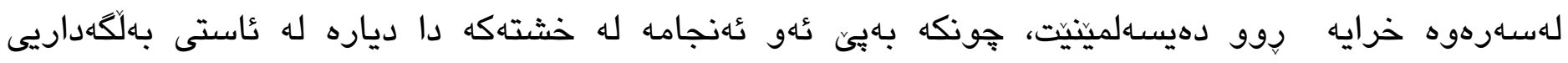

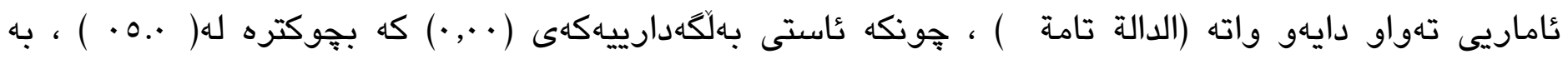

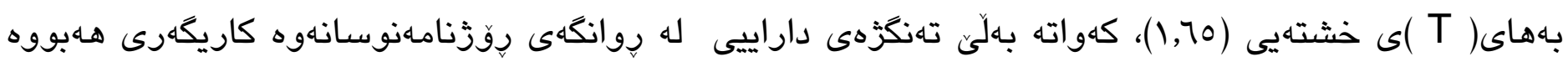

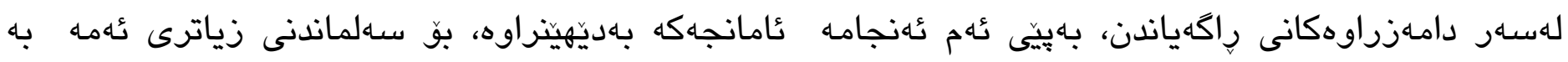

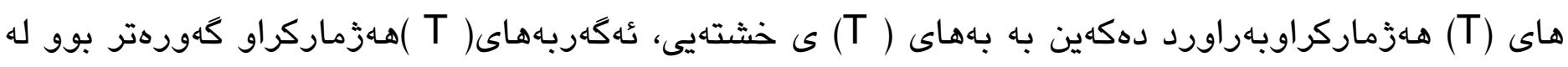

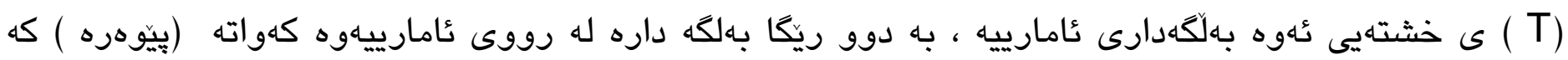

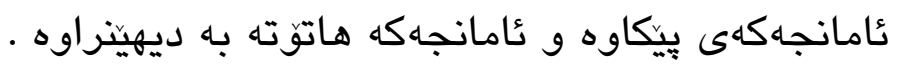




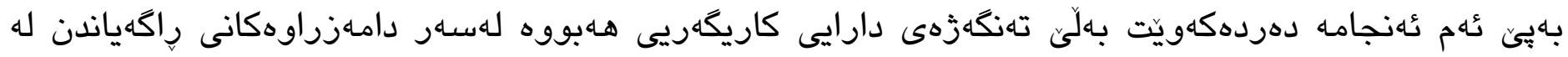

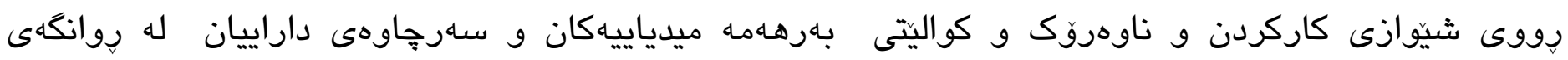

روّزنامهنوسان و كارمهندانهوه بروانه خشتهانى (1).

\section{One-Sample Statistic}

\section{T-Test}

خشتهى(1) ثاستى كاريكهريى تهنكزهى داراييى لهسهر دامهزراوهكان له بِوانكهى روزنامهنوسان

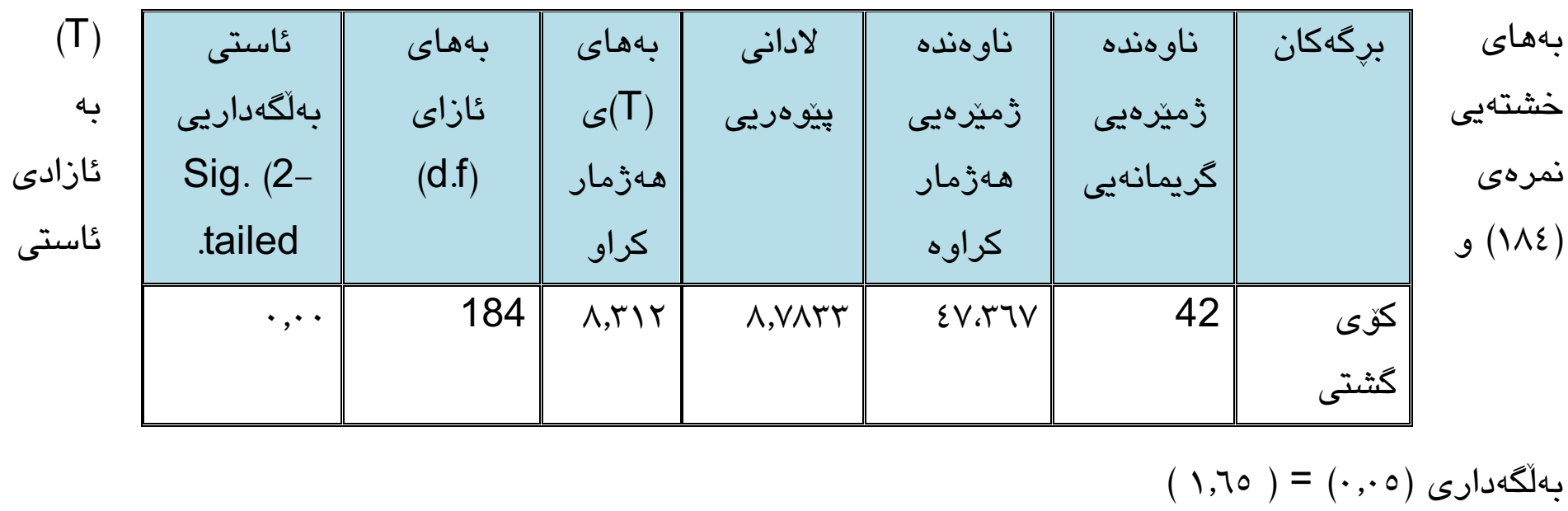

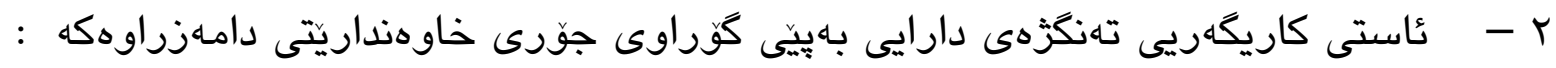

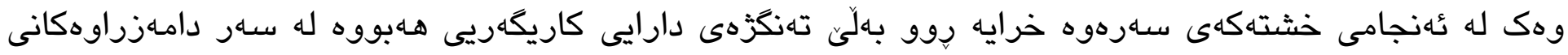

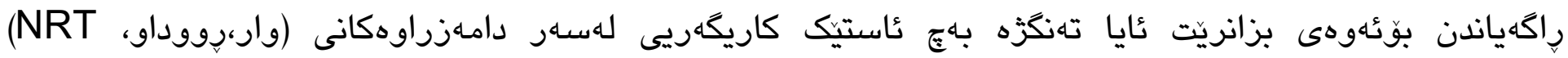
دروست كردوه ، بو زانينى ئاستى جياوازى كاريكارييهكهى له سـاهرههريهك له (كَّراوهكان) دامهزراوهكان،

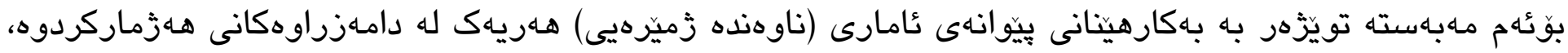

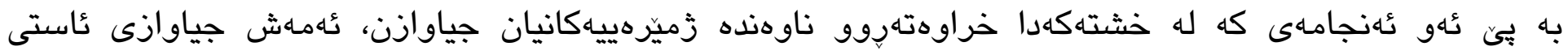

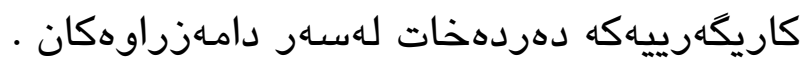

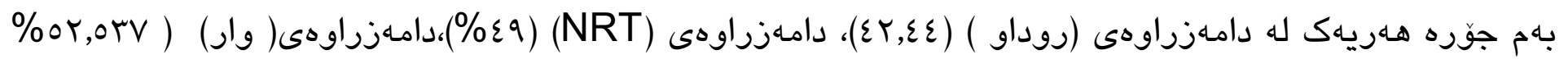

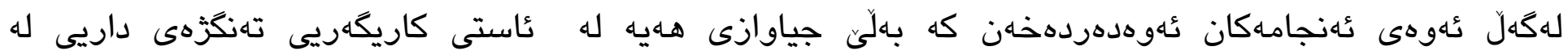

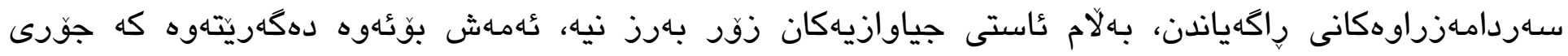

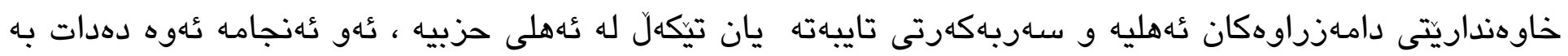


دهستهوه كه تهنكزهى داراييى كاريكهريى هابووه لهسهريان بهلاّم به بونى جياوازيهكى كهم له نيّوانياندا، بهلاّم به

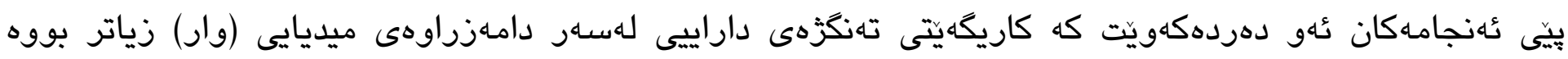

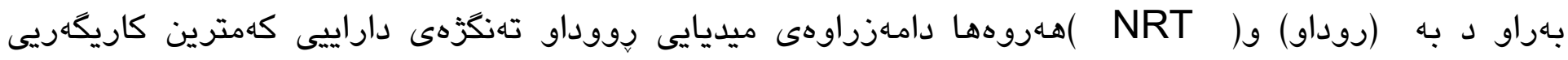

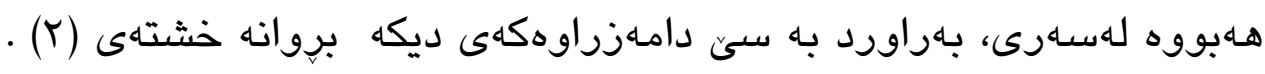

خشتهى (Y) ناوهنده زميّرهيى دامهزراوهكانى راكهياندن

\begin{tabular}{|c|c|c|c|}
\hline $\begin{array}{l}\text { Std. لادانى بيّوهريى } \\
\text { Deviation }\end{array}$ & ز زميّرهىى & زماره & دامهزر راوهكان \\
\hline 8.73521 & 42.4474 & 76 & رووداو \\
\hline 6.53275 & 49.0909 & 55 & NRT \\
\hline 7.16573 & 52.5370 & 54 & WAAR \\
\hline 8.78332 & 47.3676 & 185 & كوى كُشتى \\
\hline
\end{tabular}

ז- ئهنجامى شيكارى جياوزى يهك ئاراسته بو دهرخستنى ئاستى جياوازى كاريكهريتى تهنكزّهى داراييى لدنيّوان دامهزراوهكان و له ناو دامهزراوهكاندا.

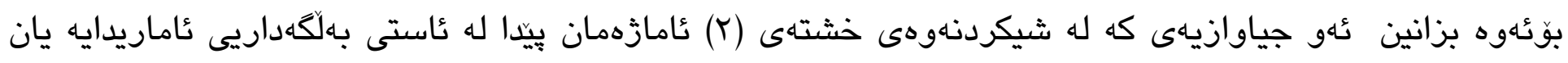

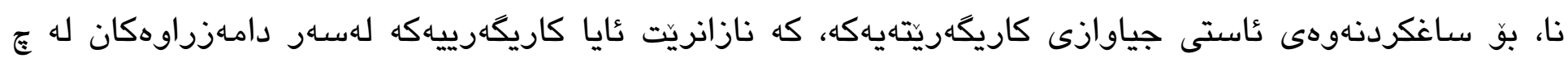

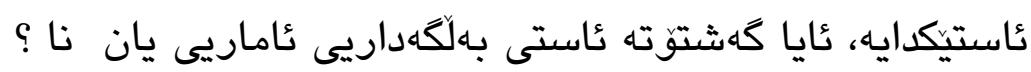

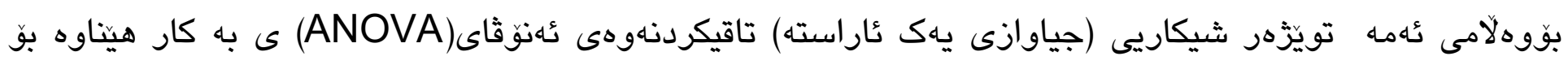

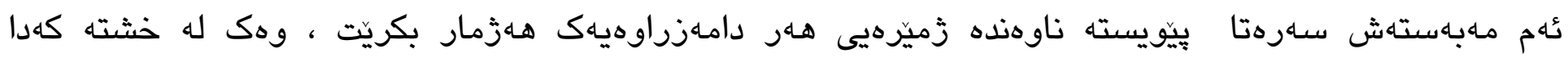

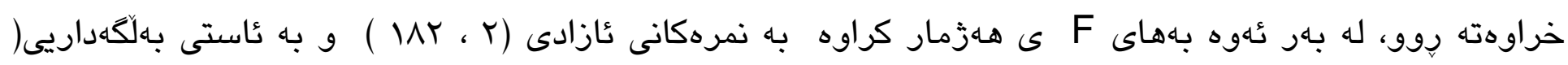

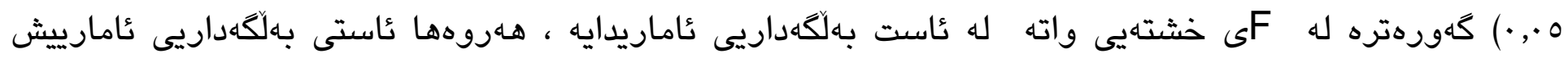

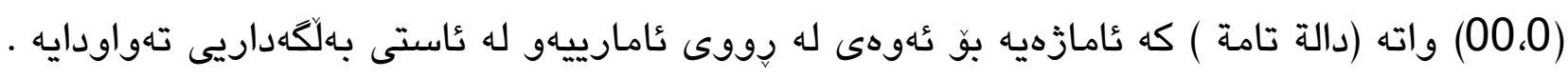

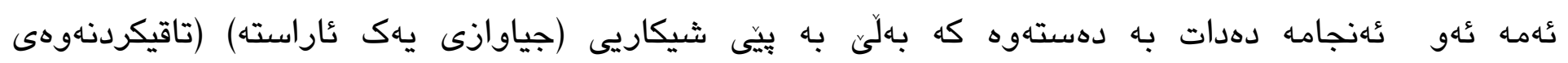

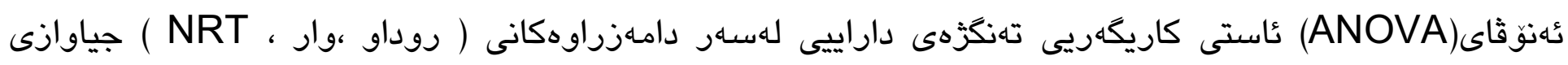


هايه، به بئ جياوازى دامهزراوهكان، واته تهنكزهى داراييى ناستى كاريكهرييهكهى له دامهزراوهيهكهوه بو دامهزاوهيهكى ديكهى رإكهاندن جياوازه.

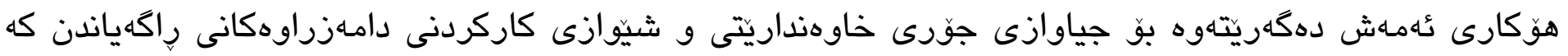
كاريكارى راستهوخو دروست دهكات لهسهر سهرجاوهى داراييى دامهزراوهكهو ئهو داهاتهى كه دهستى دهخات،

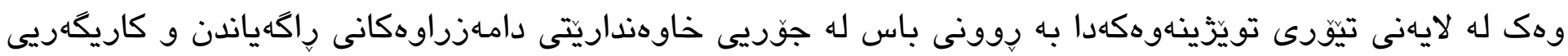

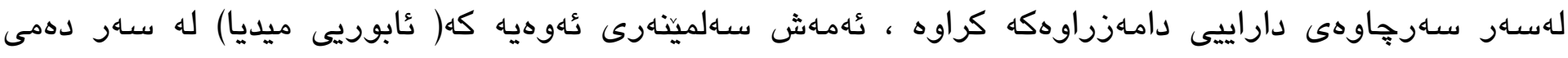

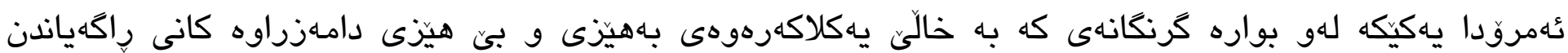

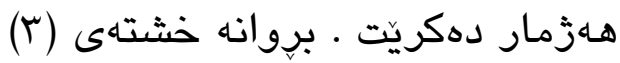

خشتهى (r)شيكارى جياوزى يهك ناراسته بو ئاستى جياوازى كاريكهريتى تهنكزهى داراييى له نيوان دامهزراوهكان

\begin{tabular}{|c|c|c|c|c|c|}
\hline 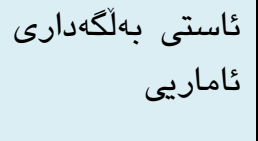 & هـهاهماى (ف) كراو & دوجاى ناوهنده & نمرهازادى نع & كَّى ناوهنده & سياهرجاوهى \\
\hline \multirow[t]{3}{*}{$\cdot, \cdots$} & $r q, I V 7$ & IVYT,IY & r & $r \varepsilon \varepsilon\rceil, Y \varepsilon$ & $\begin{array}{c}\text { له نيّوان كوَمهلّكاندا } \\
\text { Between } \\
\text { Groups }\end{array}$ \\
\hline & & $09, .09$ & MN & $1 \cdot V \varepsilon \wedge, \vee\urcorner$ & $\begin{array}{l}\text { له ناوكوَمهلَّكاندا } \\
\text { Within Groups }\end{array}$ \\
\hline & & & $\backslash \wedge \varepsilon$ & $\mid \varepsilon 190, \cdots 0$ & كوى كَثتى \\
\hline
\end{tabular}

وهك له خشتهى (ץ) خراوهته روو به بيّى ثٔهنجامى شيكاريى يهك ئاراسته جياوازى هاهيه له ئاستى

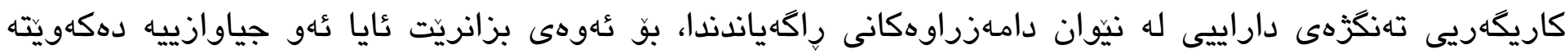

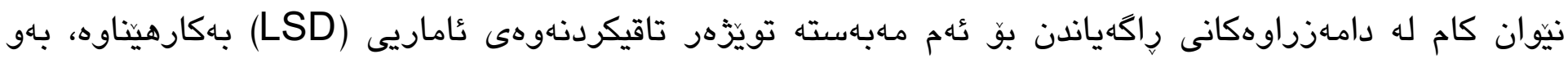

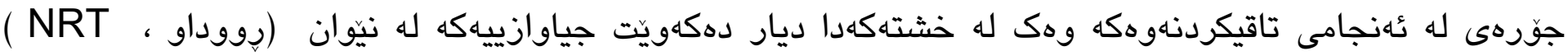

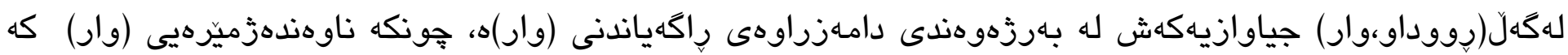

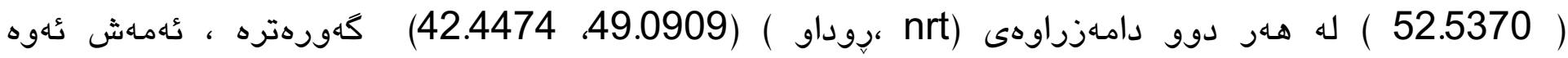

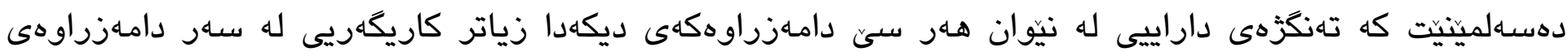

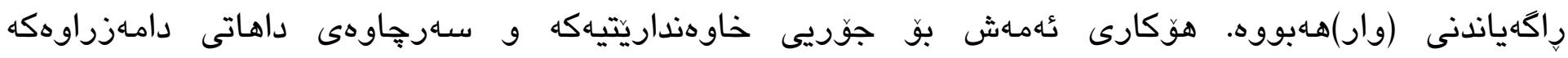
دهكکريتهوه. 


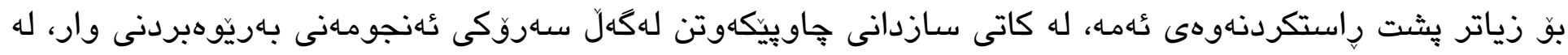

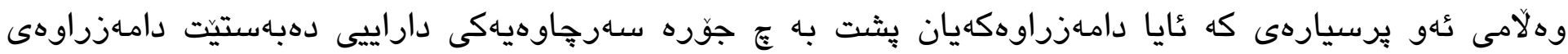

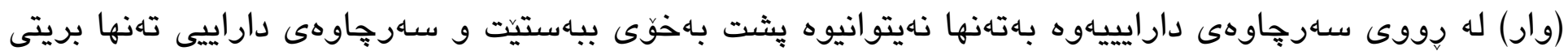

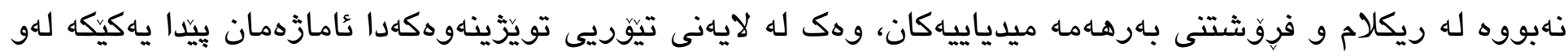

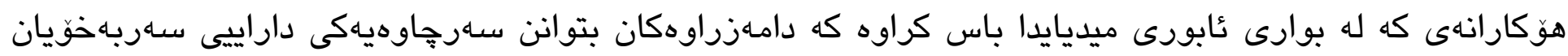

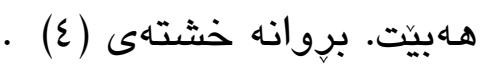

خشتهى (ع) ئهنجامى تاقيكردنهوهى (LSD) بوزانينى ئاستى جياوازى كاريكينيهكه له نيوان دامهزراوهكاندا

\begin{tabular}{|c|c|c|}
\hline $\begin{array}{l}\text { كاستى بهلخدهداريى } \\
\text { Std. Deviation }\end{array}$ & جياوازى ناوهندهزميّرهيى & دامهزراوهكان \\
\hline$\cdot, \cdot$ & 6.64354 & Nواو × NRT \\
\hline$\cdot, \cdot$ & 10.08967 & رِوداو × وار \\
\hline$\cdot, r$ & r,E乏चाr & N N N N \\
\hline
\end{tabular}

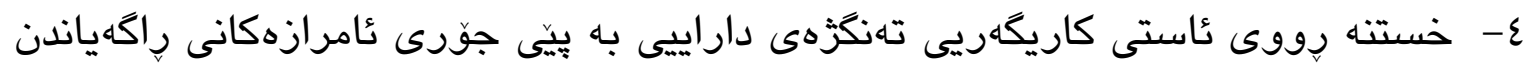

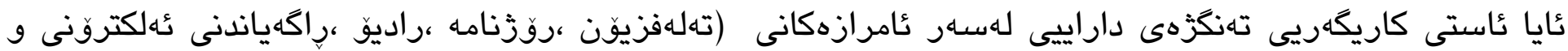

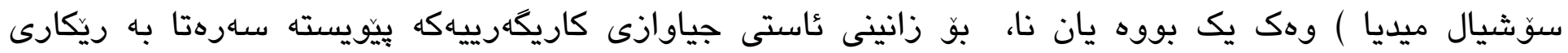

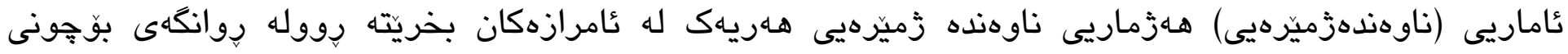
روزنامهنوسان وكارمهندانى دامهزروهكانى رِاكهياندنهوه. وهك له خشتهكها خراوهته روو جياوازييهكى ئهو تو نيه

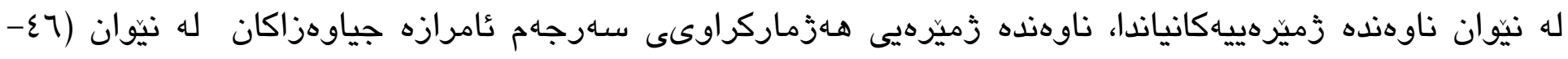

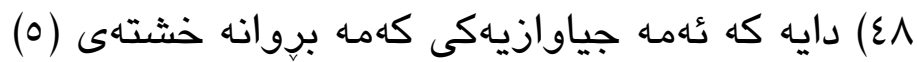


خشتهى (0)هـزماريى ناوهندهزميّرهيى لهسهر بنهماى جوّرى ثامرازهكانى راكهياندن

\begin{tabular}{|c|c|c|c|}
\hline $\begin{array}{l}\text { بكاسكاداراييى ئاماريى Std. Deviation } \\
\text { باستى }\end{array}$ & ناوهنهزَميَرهيى & ز زماره & ئامرازهكانى جوَىى \\
\hline 7.85340 & 47.6957 & 23 & روَذنامه \\
\hline 9.21037 & 47.5130 & 115 & تهله فزيون \\
\hline 7.59735 & 46.5833 & 12 & راديو \\
\hline 8.43595 & 46.3704 & 27 & ئهاكهياندنى \\
\hline 9.44817 & 48.8750 & 8 & سوّيال \\
\hline 8.78332 & 47.3676 & 185 & كؤى كَثتى \\
\hline
\end{tabular}

بو زانينى ئاستى جياوازى كاريكهريى تهنكزهى دارايى له سهار ئامرازهكانى رِاكهياندن، بوّ ساغكردنهوهى

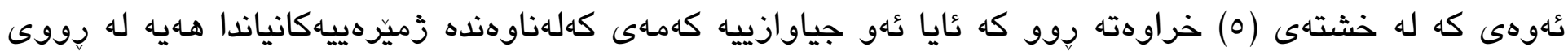

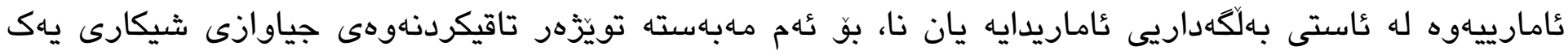
ئاراستهى (ANOVA) عى بهكارهيناوه.

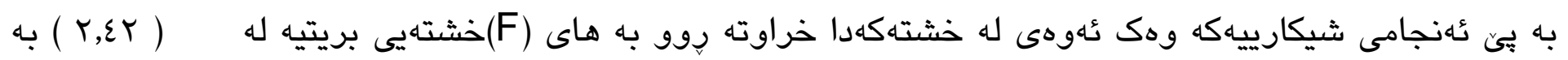

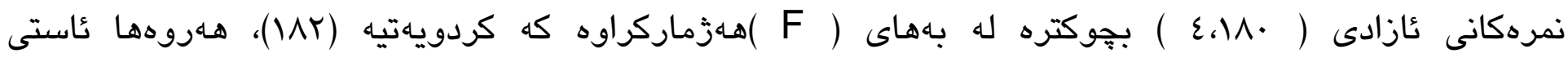

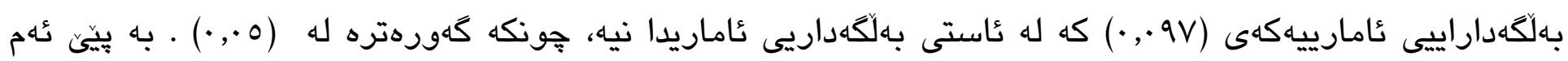

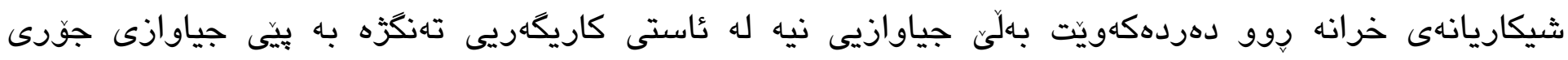
ئامرازهكانى رِاخهياندن.

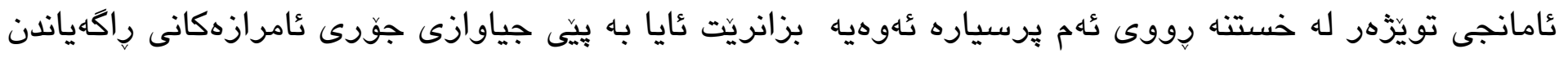

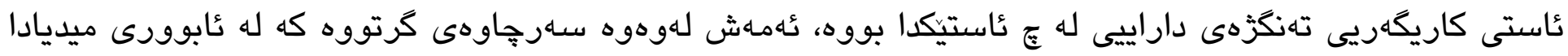

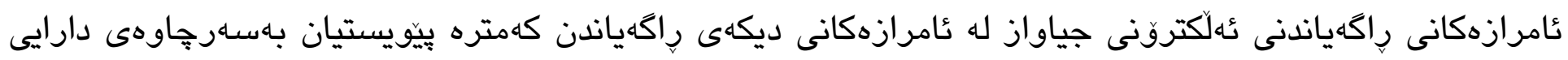

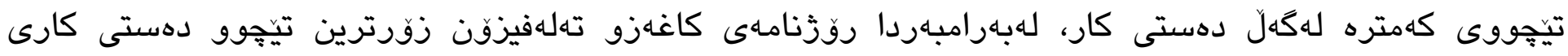

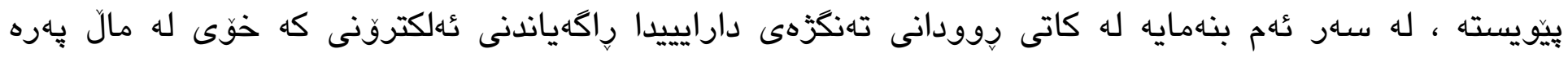

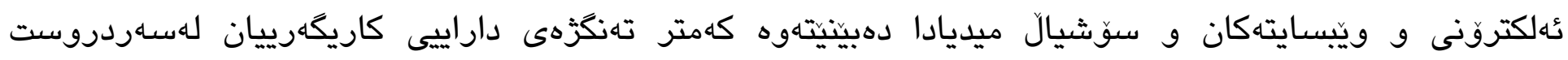

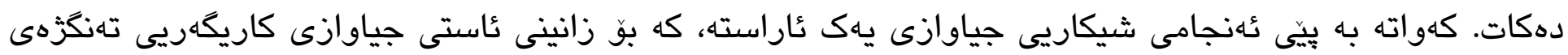




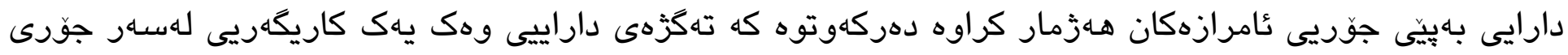

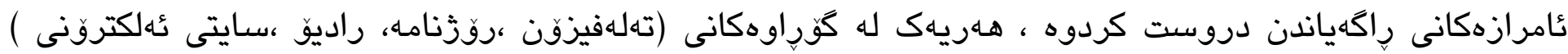

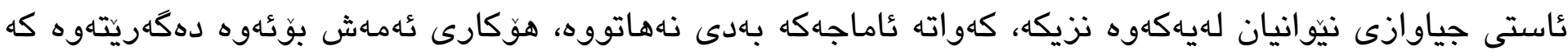
دامهزراوهكانى راكهياندن بهتايبهت دامهزراوه كَهوهكان بهشيّوهى باكيّج كار دهكهن .

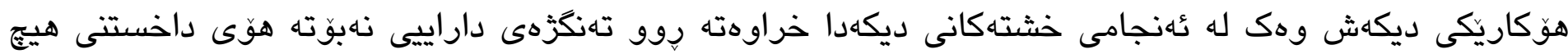

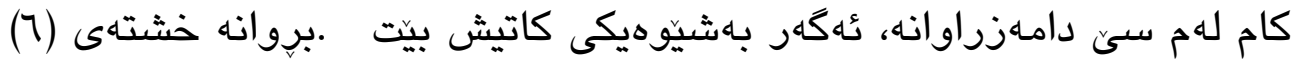
خشتهى (7)ئهنجامى شيكارى جياوزى يهك ئاراسته زانينى ئاستى جياوازى كاريكَهيى تهنكزّهى داراييى له جوّرى (ANOVA) عامرازهانى راكهياندن

\begin{tabular}{|c|c|c|c|c|c|}
\hline بـاسلاستى دارارى & 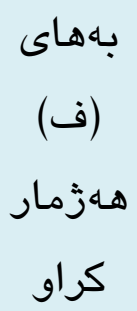 & ثناوهنده دونيّى & نمرهازادى & كؤى ناوهنده & سيارجاوهى \\
\hline 0.182440 & $M N Y$ & $\begin{array}{c}14.32936 \\
0\end{array}$ & $\varepsilon$ & $\begin{array}{c}57.317442 \\
4424422\end{array}$ & 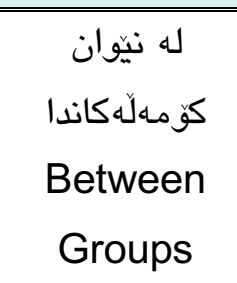 \\
\hline & & $\begin{array}{c}78.54271 \\
0\end{array}$ & $1 \Lambda$. & $\begin{array}{c}14137.687 \\
962963\end{array}$ & 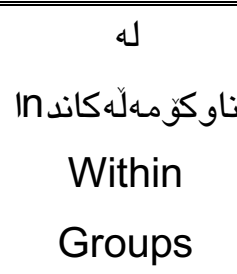 \\
\hline & & & $1 \wedge \varepsilon$ & $\begin{array}{c}14195.005 \\
4054054\end{array}$ & كوى كَتى \\
\hline
\end{tabular}

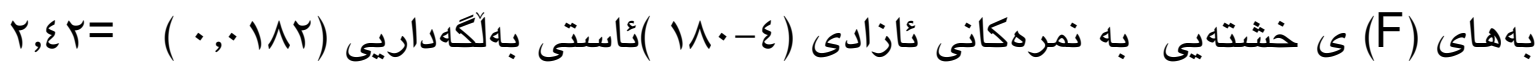




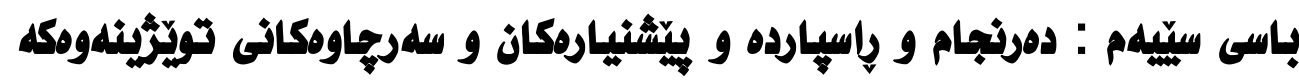

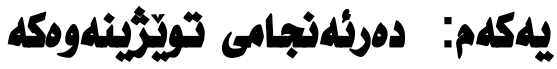

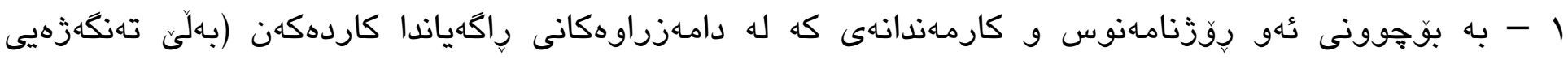

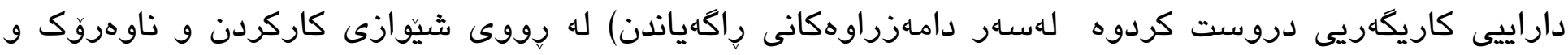

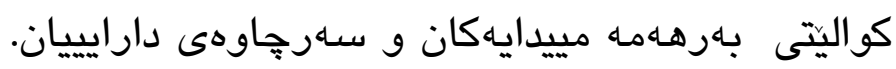

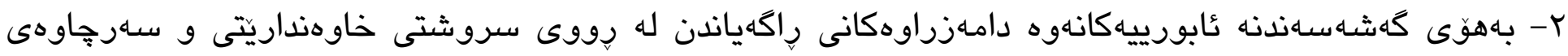

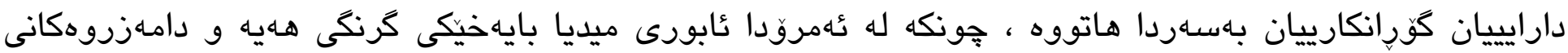

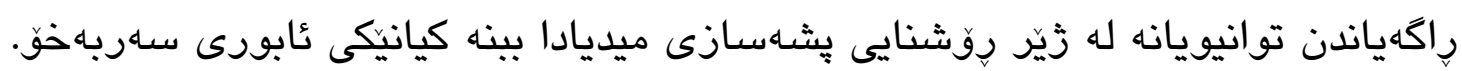

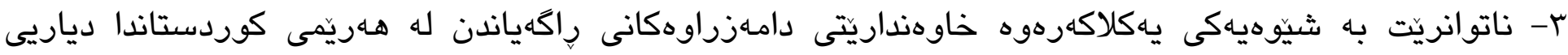

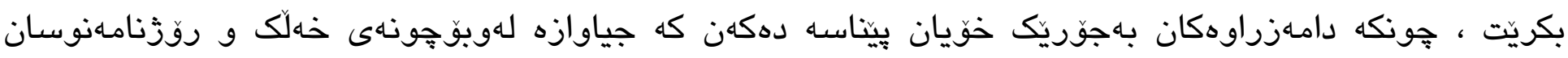

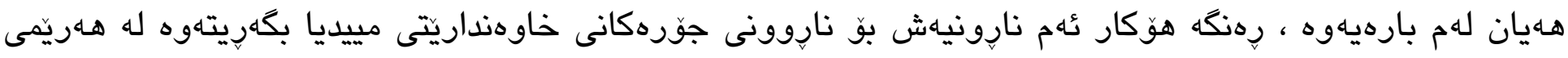
كوردستاندا، بهوَى سيستمى سياسى و ئابوريياوه.

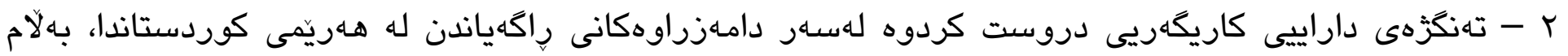

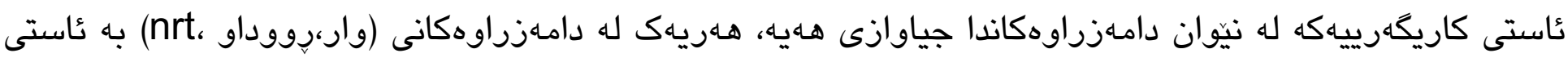

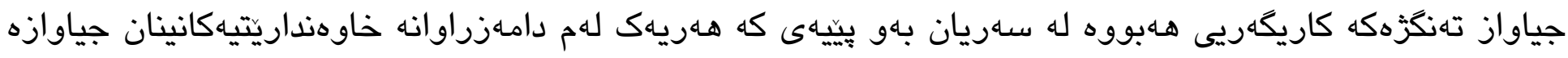

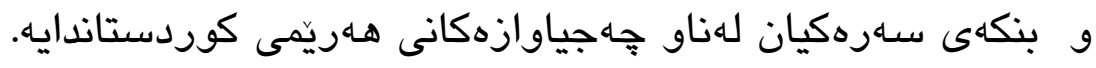

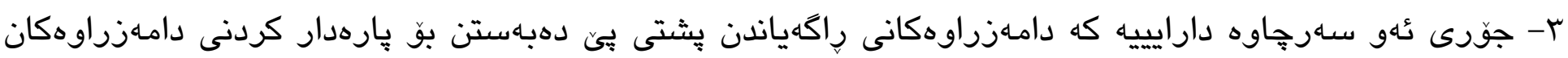

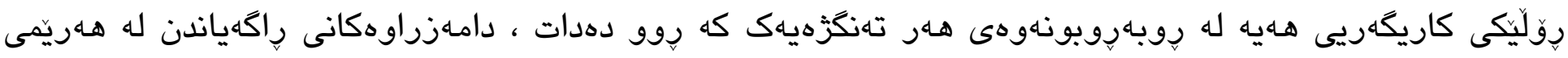

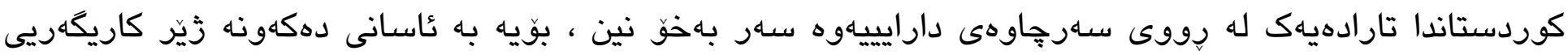
تهنكزهى دارايييهوه .

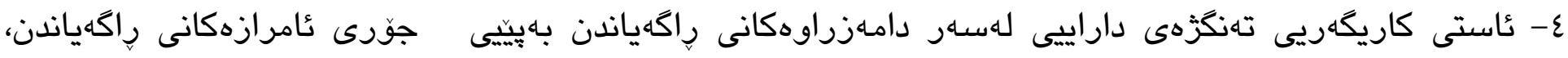

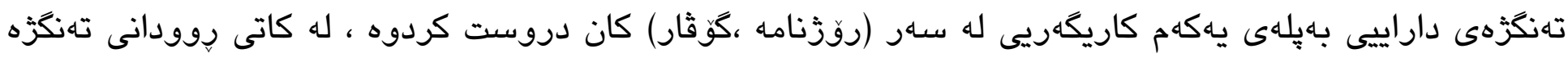

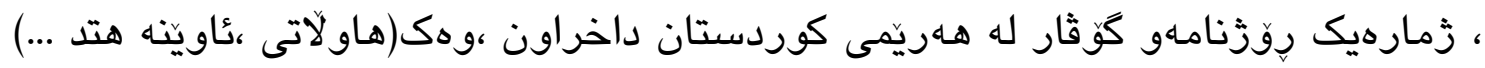

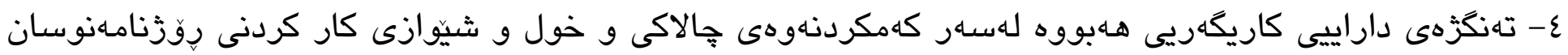

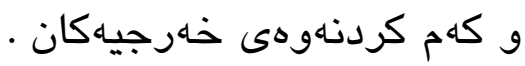




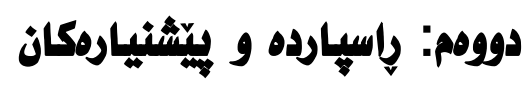

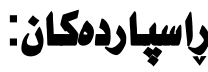

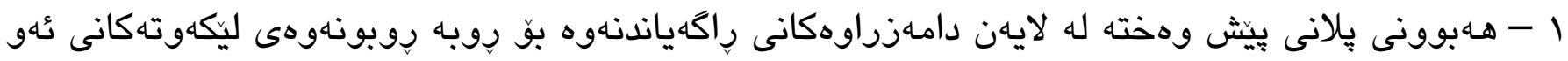

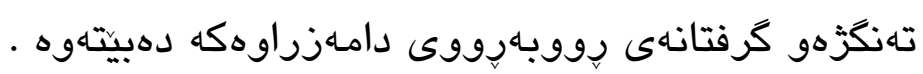

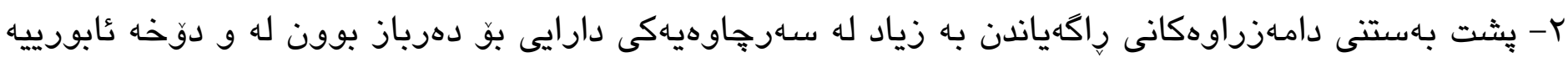
نهخوازراوانهى كه دينّه بِيش.

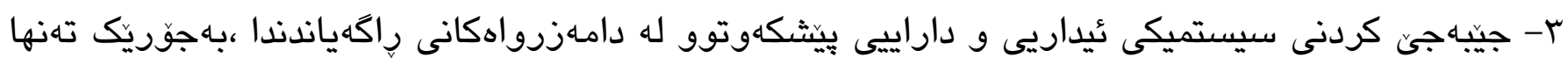

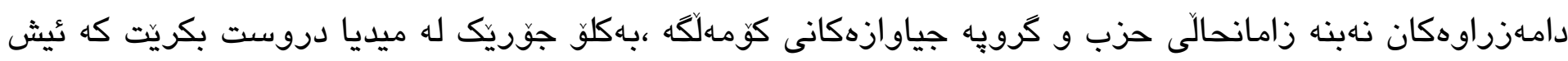

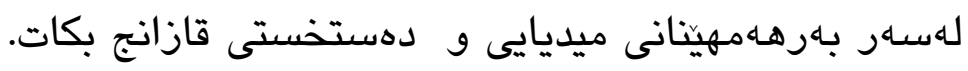

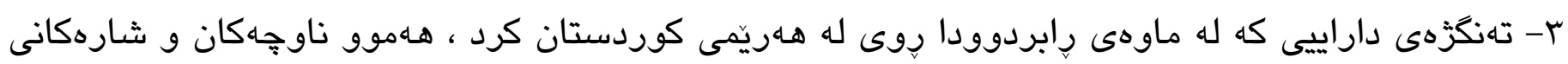

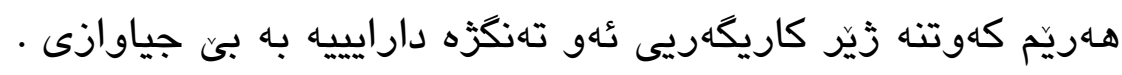

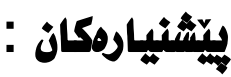

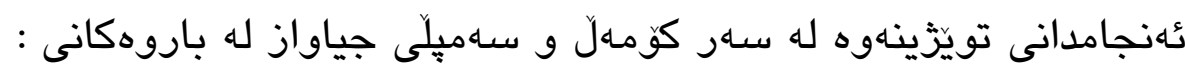

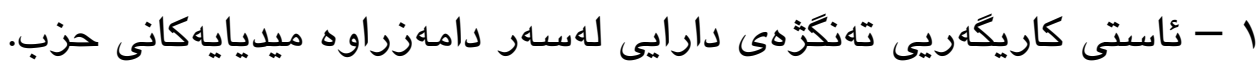

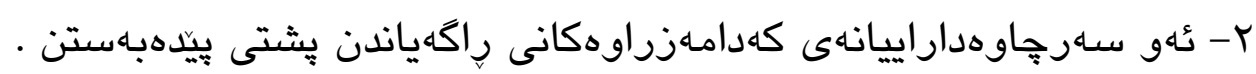

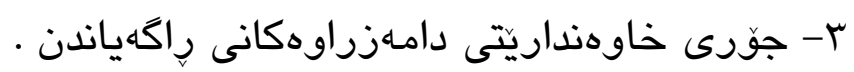

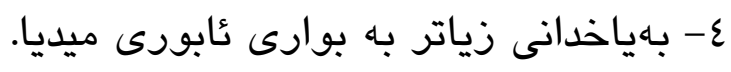

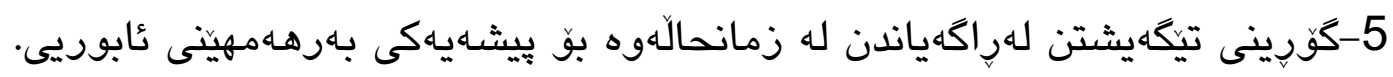




\title{
The Impact of the Financial Crisis on the Financial Sources of Media Institutions in the Kurdistan Region
}

\author{
Jwana Salah Hussein \\ Media department, College of Humanities, University of Sulaimani, Sulaimani, Kurdistan \\ Region, Iraq. \\ E-mail: jwansalah80@gmail.com
}

\section{Omar Ahmed Ramadan}

Media department, College of Humanities, University of Sulaimani, Sulaimani, Kurdistan Region, Iraq.

E-mail: jwansalah80@gmail.com

\begin{abstract}
:
The research highlights the effects of the financial crisis on Media's institutions in the Kurdistan Region. The research is excerpted from the Master's thesis (The Impact of the Financial Crisis on the Financial Sources of Media Institutions in the Kurdistan Region) and it is a Media and Economic Subject at the same time The aim( goal) of the research : to show the extent of the impact of the financial crisis on the performance and how to work in medias institutions, according to the type of owner of the institution and the type of media. In order to reach the mentioned goal, the research used the survey method. In the process of collecting information, use the questionnaire (scale) by distributing it to employees and employees of Media's organizations. The research consists of three main sections The first section: It consists of the research methodology The second section: It is the theoretical aspect of the research and consists of two issues. The first issue: The occurrence of the financial crisis in the Kurdistan Region, factors of its occurrence and its implications. The second issue: the financial sources of media organizations and their economic peculiarities. The third and last chapter: It is the practical and field aspect of the research, and it includes the results and suggestion.
\end{abstract}

key words: The Financial Crisis, Impact, Media Institutions, Financial Sources. 


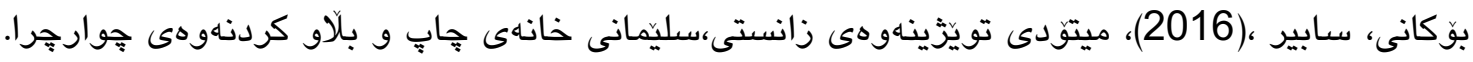

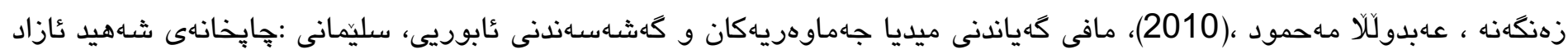
هـاورامى.

عهلى ، فهيسهل ، (2013) ،ئابورى نيّوددولَّتى له دهر ئهنجامى قهيرانهكاندا ، وهزاردتى روّشنبيرى و لاوان بهريّوهبهريتى كثتى جابِ و بلاّو كردناهوه ، سليمانى.

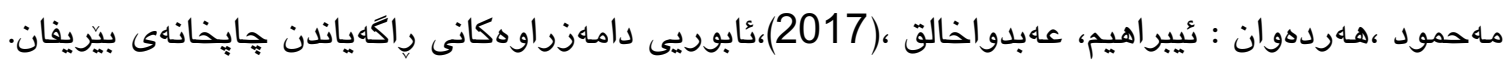
احمد، السيدسميرة ، (199V)، مصطلحات علم الاجتماع ، المملكة العربية السعودية مكتبة الثرقية .

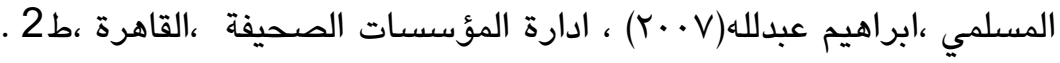
الحسن، حسان محمد: زينى عبدالحسين (Y1911) ،الاحصاء الاجتماعى ،الموصل : دار الكتب للطبعة والنثر .

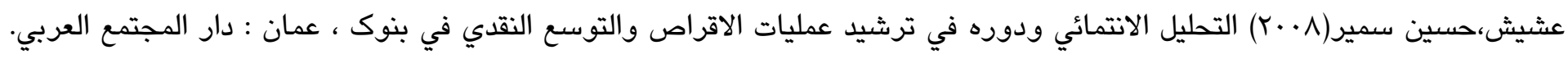
Abbas' Noori The Economic Crisis in kurdstan Region and its Impact on Foreign InvestmemtAvailable: https://www.omicsonline.org/open-access/the-economic-crisis-in-kurdistan-re سةرداني الرماني ، زيربن محمد(2005) ، اقتصاديات الاعلام اسرار واخبار ،الرياض :مكتية الرشد . زامل ، سلام منعم( 2017) ،اقتصاديات وسائل الاعلام ،نور للنشر · الشجيرى ،سهام ( 2014) ،الاقتصاديات الاعلام ، الايمارات، الط 1. مـنكورى ، شيّركو (2012) ،واقع الصحافة باقليم كوردستان العراق في ضوء نظريات الصحافة ،السليمانية. عبد الحميد ، صلاح(2018) ، الاعلام السياسى ، مصر: الجيزه. 
،هيربرت ، م. بلالوك( 2000) ،الاحصاء الإجتماعي،ترجمة:عثمان الحسن محمد و سليمان محمد رضوان، الرياض : مكتبة العبيكات .

سنو ، مى العبد الله (2006) ، نظريات التصال, بيروت: دار النهضة العربية .

الهبيتي ، هادي نعمان(2000)، التصنيع وانثاء سوق ثقافية عربية مشتركة ,الدورة الثانية والعشرون لمؤتمر الوزراء المسؤؤلين عن

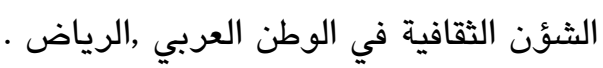

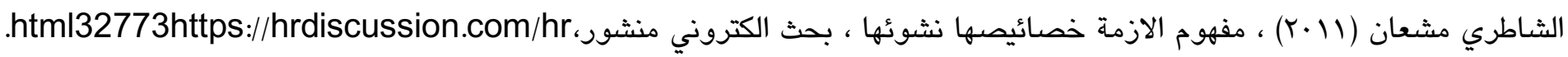

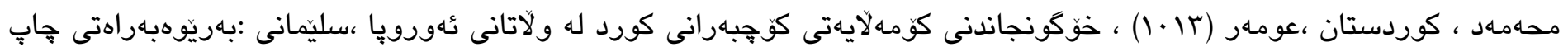

و بلاوكردنهوه ى سلينمانى

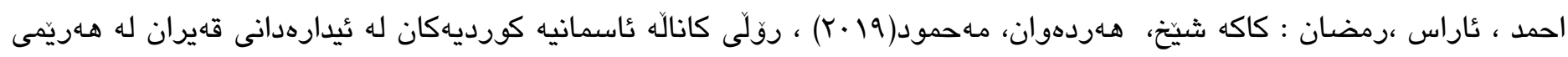
كوردستاندا قهيرانى داراييى بهنمونه ) تويَزْينهوهيكى وهديفيه.

علي، حمدي ،بشير محمد(Y) (Y) ،الاعلام الرقمي واقتصاديات صناعته ،بحث مشاريك في المنتدي الاعلامي السنوي السابع للجمعية

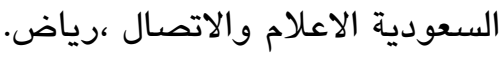

لادمية ، عابدي(V) ال الاتصال الاسري في ضل التكنولوجيات الحديثة للاعلام والاتصال ،رسالة مقدمة لنيل شهادة دكتوراه علوم

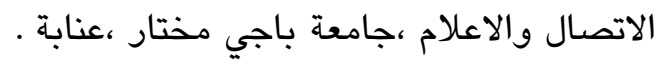

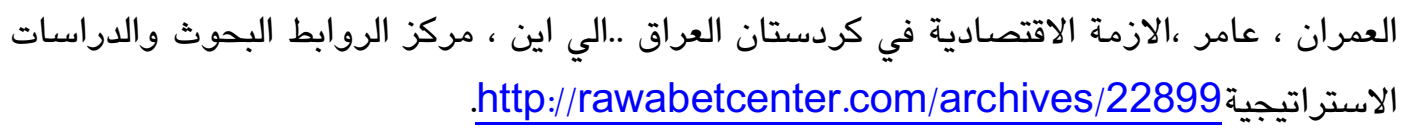

جلاط رجاء، دور الاتصال في ادارة و تسيير المؤسسة الاعلامية ،بحث منشور ، جامعة الدكتورمولاي الطاهر،كلية العلوم

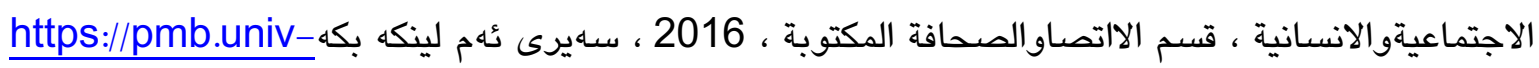
9119saida.dz/busshopac/index.php?|v|=notice_display\&id=

IIR_Making Ends Meet ، مارك ديويفر، حينما تلتقي النهايات الاصلاحات الاقتصادية في اقليم كردستان العراق سماهيرى ئهم لينكه بكه DeWeaver_Arabic.pdf

دبدوب ، مروان عبدالعزيز (•(Y) ،استخدام مصفوفةرتباط مقترحة في التحليل ألعاملي ، (قسم الاحصاء والمعلوماتية ،جامعة موصل )

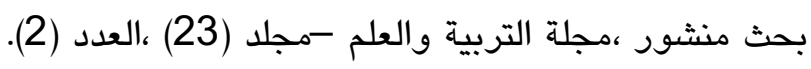

